\title{
UMA CIDADE PARA ALEMÃES CATÓLICOS: Formação e evolução urbana de Itapiranga (SC)
}

\author{
Suélen Cristina Mazzardo \\ Universidade Federal de Santa Catarina \\ Universidade do Oeste de Santa Catarina \\ suelen.mazzardo@gmail.com \\ Luiz Eduardo Fontoura Teixeira \\ Universidade Federal de Santa Catarina \\ fontourateixeira@gmail.com
}

\section{RESUMO}

O presente artigo reflete sobre o processo de evolução urbana de Itapiranga, um pequeno município da região extremo oeste do estado de Santa Catarina, cuja colonização foi impulsionada pela atuação de uma associação jesuíta que pretendia formar uma colônia étnica e confessional para descendentes de alemães católicos. Partindo da hipótese de que Itapiranga segue características peculiares de implantação das cidades criadas por alemães e seus descendentes no Brasil, a pesquisa buscou analisar o processo de ocupação territorial, crescimento e desenvolvimento urbano a fim de identificar os condicionantes e os fatores que influenciaram sua implantação, compreendendo como ocorreram as formas de apropriação do ambiente natural e de constituição dos espaços urbanos. Por meio de pesquisa bibliográfica e documental, fotografias, cartografias e informações sobre a história local e regional, foi possível identificar elementos que compõe a estrutura urbana e os processos de evolução e transformação de Itapiranga ao longo de sua história.

Palavras-chave: ocupação e evolução urbana, transformação da paisagem, história urbana.

\begin{abstract}
This article reflects on the process of urban evolution of Itapiranga, a small city in the far west of the state of Santa Catarina, which colonization was driven by a Jesuit association that sought to create an ethnic and confessional colony for descendants of Catholic Germans. Starting from the hypothesis that Itapiranga follows peculiar characteristics of the implantation of the cities created by Germans and their descendants in Brazil, the research sought to analyze the process of territorial occupation, growth and urban development in order to identify the factors that influenced its implantation, understanding how the forms of appropriation of the natural environment and the constitution of urban spaces took place. Through bibliographic and documentary research, photographs, cartography and information about local and regional history, it was possible to identify elements that make up the urban structure and the processes of evolution and transformation of Itapiranga throughout its history.
\end{abstract}

Keywords: occupation and urban evolution, landscape transformation, urban history. 


\section{CONSIDERAÇÕES INICIAIS}

O presente artigo apresenta os resultados iniciais da pesquisa realizada no âmbito do Programa de PósGraduação em Arquitetura e Urbanismo (PósARQ) da Universidade Federal de Santa Catarina (UFSC), de autoria de Suélen Cristina Mazzardo, sob a orientação do Prof. Dr. Luiz Eduardo Fontoura Teixeira, acerca da gênese e do processo de evolução urbana da cidade de Itapiranga, um pequeno município brasileiro localizado na região extremo oeste do estado de Santa Catarina.

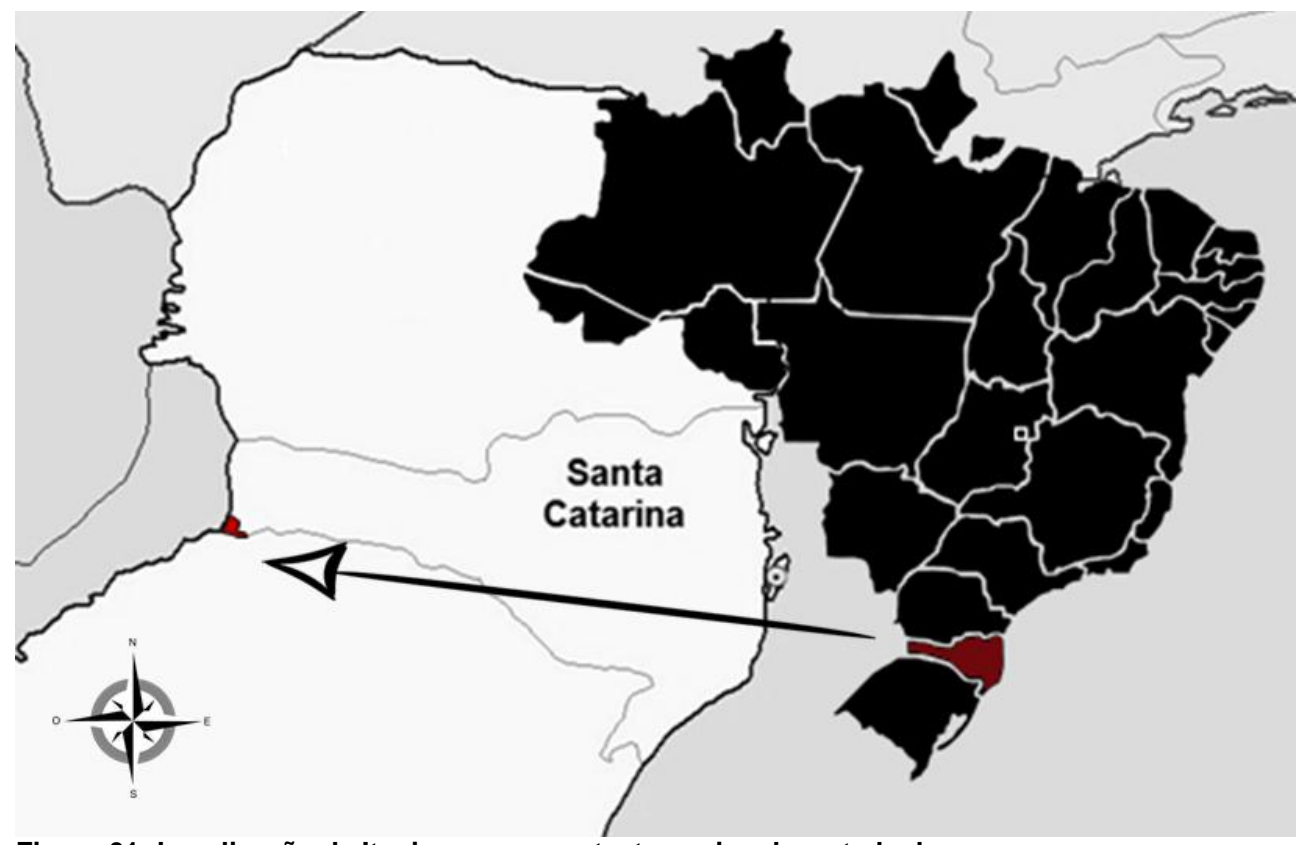

Figura 01: Localização de Itapiranga no contexto nacional e estadual Fonte: os autores (2016).

A singularidade de Itapiranga remonta ao início de sua colonização, quando denominada "Colônia Porto Novo", criada efetivamente no ano de 1926. A ocupação da colônia foi impulsionada pela atuação de uma associação jesuíta, a Volksverein für die Deutschen Katholiken im Rio Grande do Sul (Sociedade União Popular para Católicos do Rio Grande do Sul), cujo objetivo era formar uma colônia étnica e confessional para descendentes de alemães católiços, onde esses pudessem viver em comunidade, preservando seus costumes, tradições e religiosidade. É relevante destacar como outro elemento de singularidade, o plano urbano de implantação do núcleo inicial que mescla referências da cidade de origem migratória alemã, com detalhes, como o da implantação estratégica da igreja católica, típica das cidades luso-brasileiras.

Dessa forma, a pesquisa desenvolvida teve como finalidade analisar o processo de ocupação territorial, crescimento e desenvolvimento urbano de Itapiranga a fim de identificar quais foram os condicionantes e os fatores que influenciaram sua implantação, bem como compreender como ocorreram as formas de apropriação do ambiente natural e de constituição dos espaços urbanos. Levaram-se em consideração os efeitos decorrentes das dinâmicas econômicas, sociais e culturais na transformação da paisagem, resgatando, assim, a sua história urbana.

A hipótese considerada é que a cidade de Itapiranga segue características peculiares de implantação das cidades criadas por alemães e seus descendentes no Brasil. Este modelo pode ser encontrado em diversas cidades de colonização germânica, nas quais houve a necessidade de adequação à paisagem natural, formada por rios, arroios e montanhas.

Para que fosse possível alcançar os objetivos propostos, a metodologia utilizada foi desenvolvida em três etapas. Em um primeiro momento, a pesquisa bibliográfica se concentrou no referencial teórico-conceitual relacionado ao objeto por meio da leitura de publicações acerca da formação das cidades em geral e das características de implantação de sítios urbanos alemães. Posteriormente, foram realizadas pesquisas de campo a fim de coletar de dados, fotografias, cartografias e informações documentais (fontes primárias dificilmente encontráveis, dada a precariedade dos arquivos locais) sobre a história do lugar e da região, que auxiliaram na reconstituição do processo de gênese, formação e evolução urbana de Itapiranga . Por fim, foi realizado um diagnóstico da situação atual do ambiente urbano a fim de poder interpretar os dados 
coletados e analisar comparativamente o traçado urbano e as influências sobre ele. A partir desta análise foi possível identificar elementos que compõe a estrutura urbana e os processos de evolução e transformação da cidade ao longo de sua história.

\section{OBJETO DE ESTUDO}

O município de Itapiranga se localiza na região extremo oeste do estado de Santa Catarina e está implantando na margem direita à montante do rio Uruguai. Sua fundação aconteceu no ano de 1926 impulsionada pela atuação de uma associação jesuíta e por quase três décadas permaneceu como distrito do município de Chapecó, do qual se emancipou político-administrativamente em 1954.

Com $286,00 \mathrm{~km}^{2}$ de área territorial, Itapiranga está distante da capital estadual, Florianópolis, em $747 \mathrm{~km}$. Quanto aos seus limites físico-territoriais, ao norte, faz divisa com o município de Tunápolis e ao leste, com os municípios de São João do Oeste e Mondaí. Ao sul, faz divisa com o rio Uruguai e, consequentemente, com os municípios de Caiçara, Barra do Guarita, Derrubadas e Pinheirinho do Vale, pertencentes ao estado do Rio Grande do Sul, e, a oeste, encontra o Rio Peperi-Guaçú na divisa com a República Argentina (PMI, 2015).

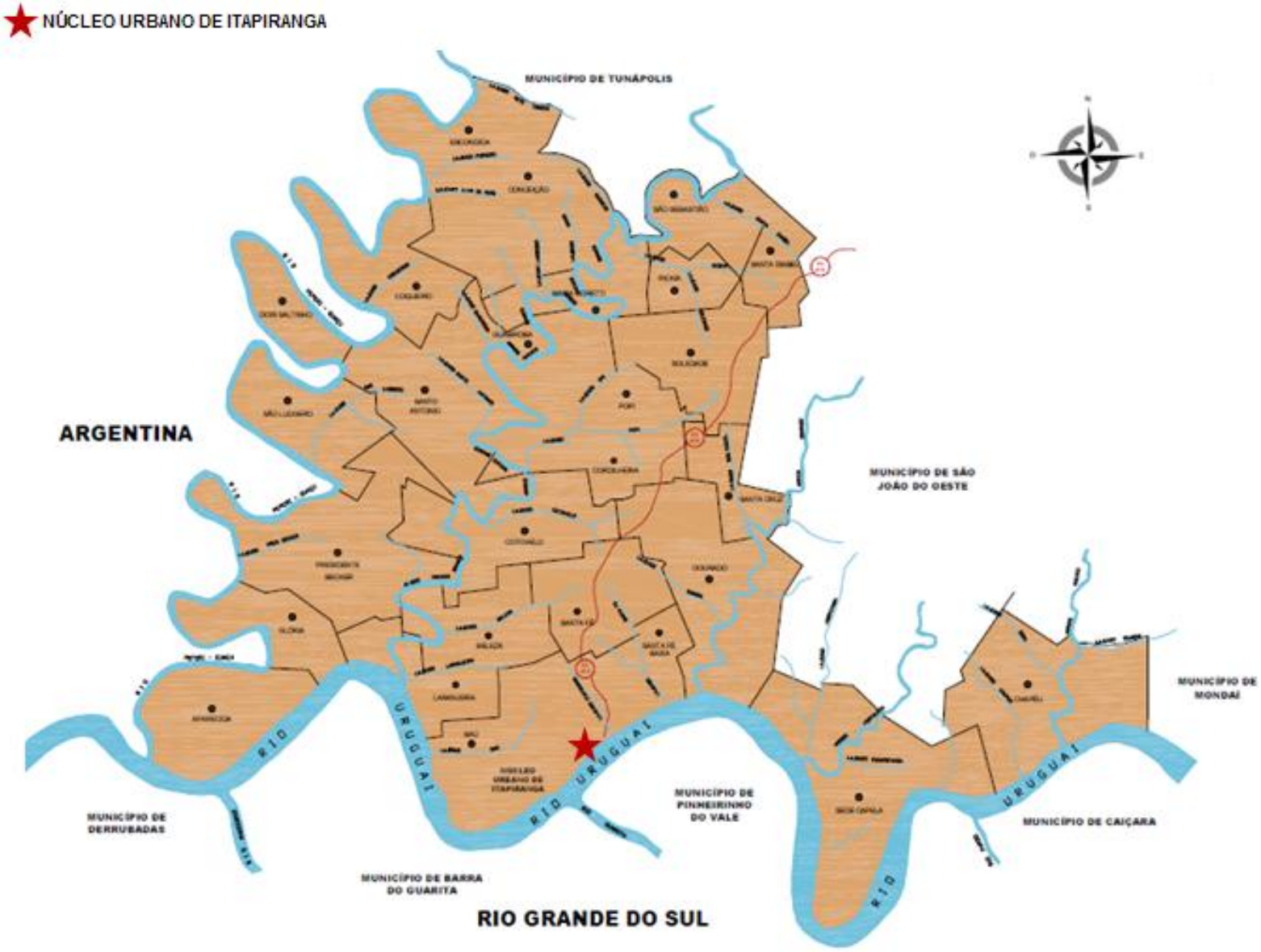

Figura 02: Divisão territorial do município de Itapiranga em comunidades, hidrografia e acesso rodoviário Fonte: elaborado pelos autores (2016) com base em dados fornecidos pela Prefeitura Municipal.

O município possui apenas uma via de acesso asfáltico, a rodovia SC 472, que conecta Itapiranga a Iporã do Oeste. A ligação com o estado do Rio Grande do sul é realizada por transporte fluvial no rio Uruguai, no qual são utilizadas balsas e pequenas embarcações para a travessia de veículos e pedestres, respectivamente. Não há conexões com a República Argentina (PMI, 2015).

De acordo com dados obtidos no último censo realizado pelo IBGE em 2010, Itapiranga possuía 15409 habitantes, sendo 7616 vivendo na área urbana e 7793 na área rural, distribuídos em 26 comunidades interioranas, 06 bairros além do centro da cidade, com 7.969 propriedades na área rural e 7.269 na área 
urbana. A partir da projeção do censo, atualmente, estima-se que o município possua em torno de 16541 habitantes. ${ }^{1}$

Itapiranga possui, como fator de formação do solo, o material de origem basalto. $O$ relevo se caracteriza como ondulado a fortemente ondulado, variando de 150 a 544 metros de altitude. Verifica-se também a presença de escarpas, planaltos e planícies, mas em menor proporção (Rhoden et al, 2015), as quais configuram belíssimas paisagens, não apenas com o rio Uruguai, mas com outros rios, arroios e lajeados que cortam o município.

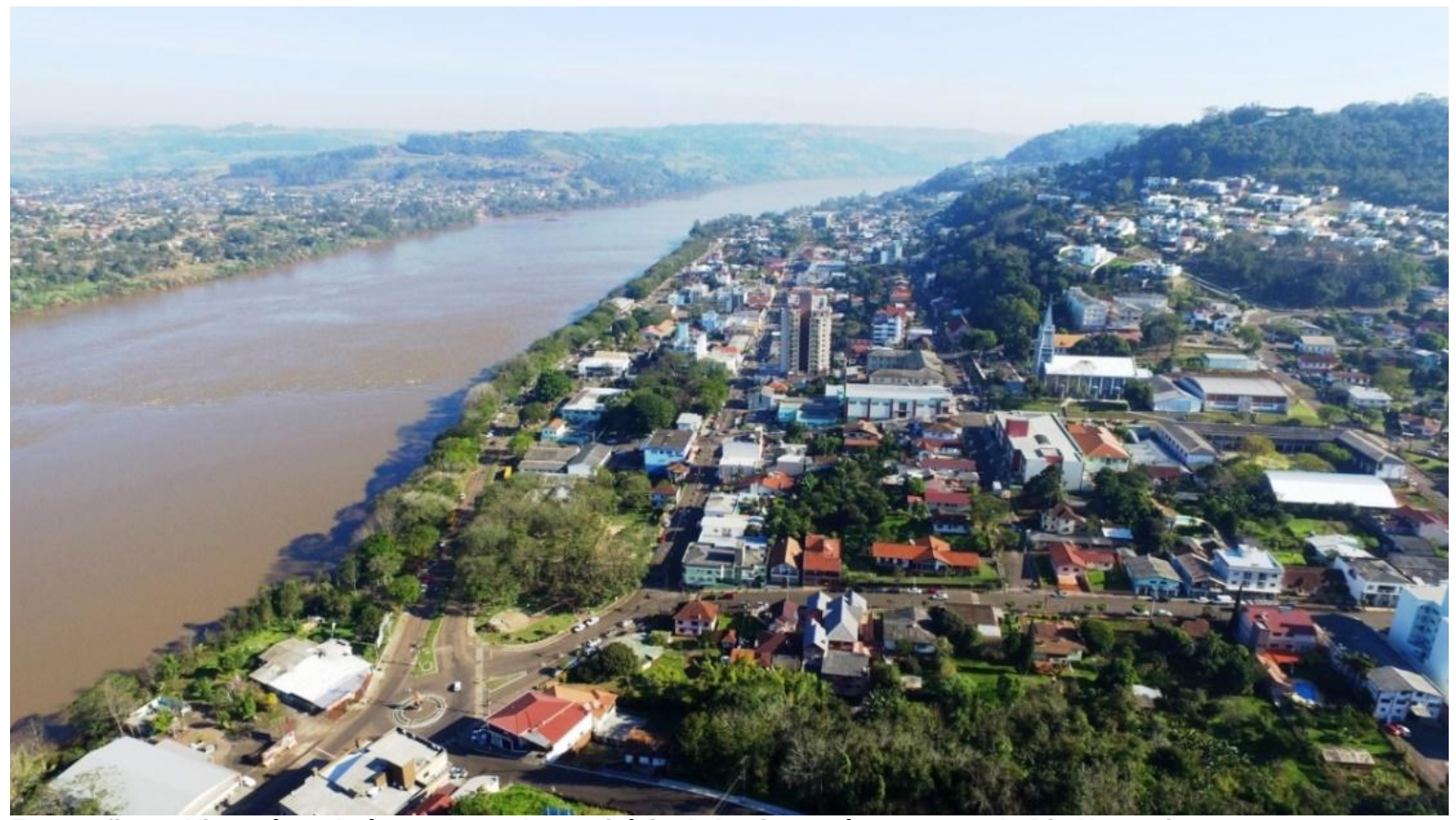

Fotografia 01: Vista aérea da área urbana do município de Itapiranga às margens do Rio Uruguai Fonte: os autores (2016)

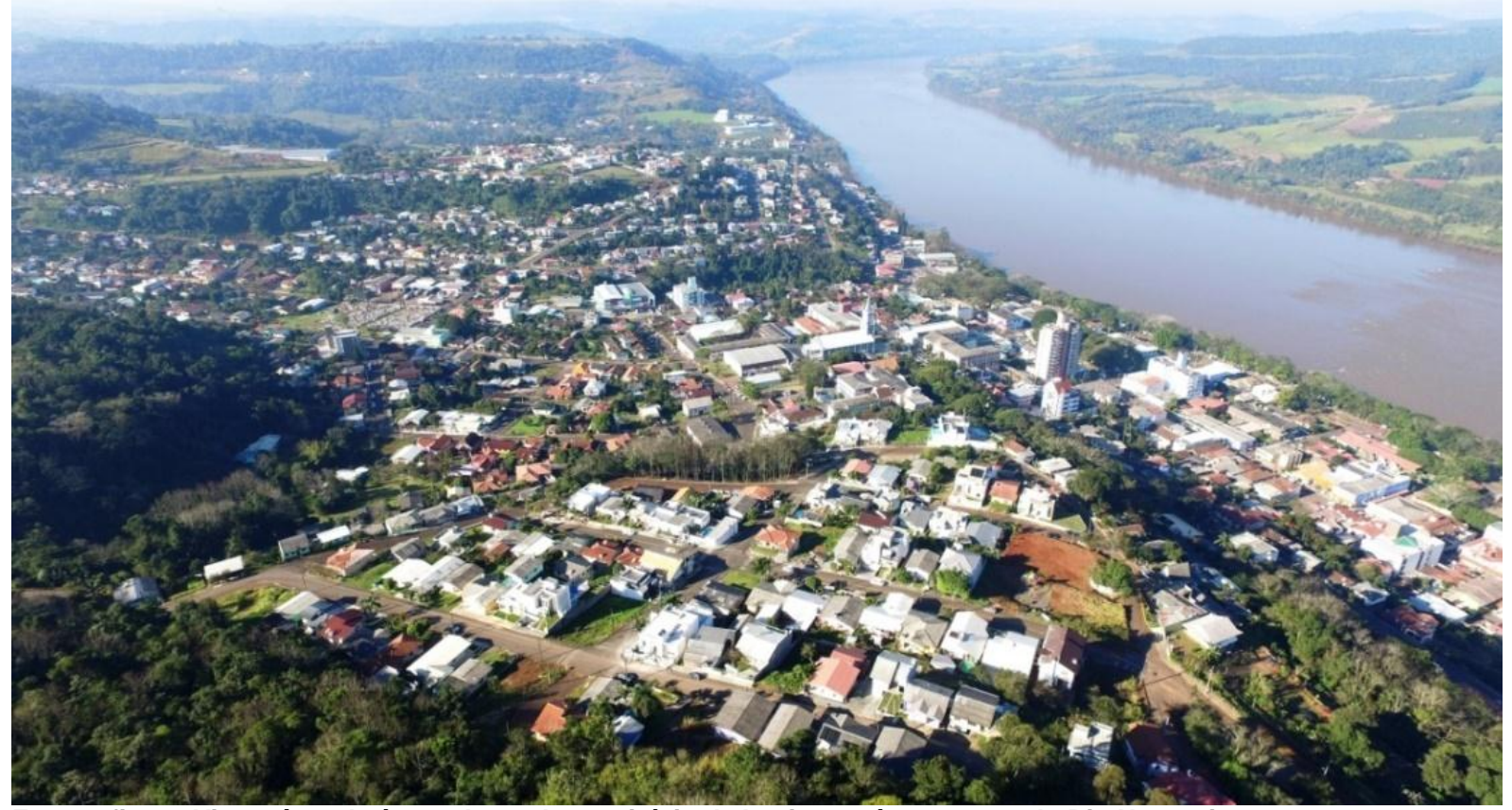

Fotografia 02: Vista aérea da área urbana do município de Itapiranga às margens do Rio Uruguai

Fonte: os autores (2016).

${ }^{1}$ Dentre os dados levantados no censo, o IBGE caracterizou 14599 pessoas como sendo de religião católica. 
O clima da região é subtropical úmido, com temperaturas que variam de $-0^{\circ} \mathrm{C}$ (mínima) a $40^{\circ} \mathrm{C}$ (máxima), resultando em uma média anual de $20,5^{\circ} \mathrm{C}$, e precipitação pluvial média anual de $1760 \mathrm{~mm}$. Em relação à vegetação, a região apresenta resquícios de Mata Atlântica. Porém, devido à atividade madeireira que por muito tempo marcou a região, atualmente, encontram-se florestas secundárias em diferentes estágios de desenvolvimento e se destacam as ações de reflorestamento (PMI, 2015). ${ }^{2}$

Durante vários anos, as principais fontes de renda para a maioria das famílias eram a extração da madeira, a produção de banha e o cultivo de fumo, resultando em pouca integração da economia local com os mercados estadual e nacional. Atualmente, a base da economia é a agropecuária, onde se destacam o cultivo de milho, fumo e feijão e a criação de aves, suínos e gado de leite, além da produção de hortifrutigranjeiros. Grande parte desta produção acontece em pequenas propriedades de agricultura familiar, porém, essas se integram às agroindústrias de carnes, laticínios, fumageiras e fábricas de cereais da região. O município conta com inúmeros estabelecimentos comerciais e de serviços, porém, a base de geração de empregos está na indústria de transformação, compreendendo às já mencionadas agroindústrias, os abatedouros e derivados, as indústrias moveleiras, marcenarias, fábricas de estofados e metalúrgicas (Hahn, 2005).

\subsection{A imigração alemã no Brasil e a colonização do oeste catarinense}

A vinda de alemães para terras brasileiras se insere no contexto de motivações gerais da emigração europeia, causadas por transformações políticas, econômicas, sociais e culturais, sendo a consolidação do Estado Nacional Alemão o principal fator para o crescimento do fluxo migratório. No caso do Brasil, houve um grande investimento em propaganda para atrair os imigrantes que se dirigiram, em maior número, para as regiões Sudeste e Sul (Gregory, 2013).

A imigração entrou na pauta da política brasileira a partir do século XIX por meio da substituição, no Sudeste, do tráfico de escravos pela mão-de-obra europeia nas lavouras de café e, no Sul, pela tentativa de povoamento de núcleos coloniais localizados em áreas fronteiriças e considerados vazios demográficos (Gregory, 2013).

No estado do Rio Grande do sul, os núcleos coloniais foram se multiplicando rapidamente, resultando na derrubada de grandes extensões de mata virgem. Com o passar do tempo, os descendentes dos primeiros imigrantes enfrentaram a falta de terras em suas colônias, o que os obrigou a migrarem para outras regiões. Por volta de 1926, as frentes de colonização chegaram à margem direita do rio Uruguai, no oeste do estado de Santa Catarina (Rambo, 2011).

A história do Oeste catarinense e da formação das cidades é recente apesar dessa região ter passado por diferentes fases de ocupação populacional e por disputas territoriais, as quais despertaram a atenção do governo estadual para a necessidade da criação de uma política governamental de povoamento que garantisse a posse definitiva das terras. ${ }^{3}$ Desta forma, em 1917, foram criados os municípios de Cruzeiro (atual Joaçaba) e Chapecó, este abrangia desde a divisa com a Argentina até a atual Concórdia (Paim, 2006).

Para acelerar a ocupação e garantir a posse do território oestino, o governo catarinense concedeu a empresas colonizadoras extensas glebas de terra, chamadas de terras devolutas. ${ }^{4}$ Tanto as empresas quanto a maior parte dos compradores eram descendentes de europeus da segunda e terceira gerações de imigrantes que povoaram o Rio Grande do Sul (Paim, 2006). ${ }^{5}$ As colonizadoras foram as responsáveis pelo início da ocupação do oeste catarinense ficando a cargo da organização e da infraestrutura das novas colônias, uma vez que o estado permanecia ausente durante o processo.

\footnotetext{
${ }^{2}$ A madeira mais nobre era explorada pelas empresas colonizadoras antes das terras serem vendidas aos colonos. A exportação desta madeira para a Argentina era feita por meio de balsas pelo rio Uruguai na época de enchentes (Hahn, 2005).

${ }^{3}$ Houve três fases de ocupação populacional e três fases de disputas territoriais. Quando ao povoamento: a primeira fase refere-se à ocupação indígena Kaingang até meados do século XIX; a segunda de ocupação cabocla, resultante da miscigenação indígena com luso-brasileiros; e a terceira marcada pela chegada dos imigrantes descendentes ítalo-germânicos vindos do Rio Grande do Sul no início do século XX (Poli, 1987). Quanto às disputas: inicialmente, entre Portugal e Espanha; num segundo momento, entre Brasil e Argentina e, num terceiro momento, entre Paraná e Santa Catarina, originando, inclusive, a Guerra do Contestado (1912-1916), quando só então se definiu que o território pertencia ao estado de Santa Catarina (Paim, 2006).

${ }^{4}$ Consideradas desabitadas pelo Governo do Estado, apesar de muitas dessas terras serem habitadas por posseiros.

${ }^{5}$ Estes eram atraídos pela intensiva propaganda acera do preço barato da terra, da abundância de madeira, da fertilidade do solo e das condições favoráveis para a agricultura.
} 
Neste contexto, Peluso Jr (1991, p. 292) destaca que houve uma certa omissão das autoridades brasileiras, uma vez que "a fundação de povoados no Oeste Catarinense não ocorreu em obediência a determinações oficiais. [...] As povoações, em geral, foram espontâneas, mas surgiram em decorrência das necessidades de cada núcleo colonial. Cada empreendedor olhou o problema como se sua colônia fosse única, e procurou dela tirar o máximo de proveito. Nos núcleos coloniais pequenos, havia, apenas, a sede; nos maiores, tantas povoações quanto fossem necessárias" (Peluso Jr, 1991, p. 292). ${ }^{6}$

Dentre os projetos de colonização, um se diferenciou dos demais. O "Projeto Porto Novo", colônia que em 1929 recebeu o nome de Itapiranga, foi organizado por uma associação para alemães católicos, fundada por jesuítas, a Volksverein für die Deutschen Katholiken im Rio Grande do Sul (Sociedade União Popular para Alemães Católicos do Rio Grande do Sul). A associação não era propriamente uma empresa colonizadora, mas possuía o objetivo de formar uma comunidade étnica e confessional onde os colonos alemães católicos pudessem viver, progredir e se proteger dos perigos da modernidade (Werle, 2001).

\subsection{Uma comunidade para alemães católicos}

Em 1912, foi realizado na cidade de Venâncio Aires, o nono Congresso dos Católicos, cujo tema central recaiu sobre a situação em que se encontravam as comunidades católicas alemãs no Rio Grande do Sul, em âmbito cultural, educacional, religioso e econômico. A partir dos problemas identificados, buscou-se apostar em soluções e ações para a promoção humana e o aprimoramento do nível cultural. Assim, a ideia de uma organização que abrangesse os alemães católicos e seu bem-estar corporal e espiritual foi lançada (Rambo, 2011).

A Sociedade União Popular para Alemães Católicos do Rio Grande do Sul, popularmente conhecida apenas por Volksverein, resultou como proposta do Congresso. Nesta perspectiva, foram escolhidas as prioridades de ação e as linhas estratégicas a serem seguidas priorizando o bem-estar material e espiritual dos católicos de descendência alemã. Dentre as atividades previstas, constavam: a preservação da língua alemã, a implantação de novas colonizações católicas, a promoção de escolas paroquiais católicas, a difusão da imprensa e da leitura por meio de uma publicação periódica gratuita, a assistência jurídica, a instrução popular mediante palestras e a intermediação de empregos e informações (Rambo, 2011). ${ }^{7}$

Cabe destacar a preocupação envolvendo a implantação de novos assentamentos para católicos alemães, pois para os representantes da Volksverein, a migração impulsionada apenas pelas razões de natureza econômica gerava o grande inconveniente da mistura confessional causada pelos casamentos mistos. ${ }^{8} \mathrm{~A}$ separação por nacionalidades também foi uma alternativa, pois se acreditada que "colônias mistas de alemães, italianos e poloneses não logravam organizar uma vida comunitária como era de desejar" (Rabuske; Rambo, 2004, p. 58). A exigência de serem alemães católicos não era baseada em intolerância racial ou religiosa, mas sim na tentativa de preservar a identidade étnica e a religiosidade.

Reproduzindo em seu livro de memórias os anais da Reunião de Católicos de Porto Novo em 1934, Rohde (2012, p. 25) descreve que "A Volksverein não via com bons olhos o fato de jovens agricultores gaúchos de origem alemã serem convencidos através de propaganda, a integrarem projetos de colonização que misturavam origem étnico-cultural ou confissão religiosa. [...] Única e exclusivamente a preocupação era com o bem estar espiritual e físico dos povoadores que migravam. Comunidade religiosa, escola, agremiações, mesmo associações com objetivos puramente de lazer, somente são possíveis de ser formadas e mantidas em um grupo com unidade cultural e religiosa. Mesmo que o colonizador, vivendo em meio a um grupo bem diverso, pudesse ter colheitas ricas, significaria sufocar no materialismo, basear suas decisões apenas no objetivo de alcançar ótimas colheitas. Este materialismo traria consequências devastadoras para as futuras gerações". ${ }^{9}$

Portanto, a busca pelo convívio comunitário por meio de uma mesma língua, uma mesma tradição e uma mesma confissão religiosa resumem as principais razões e motivações por trás da decisão de implantar uma colônia étnica e confessionalmente identificada.

\footnotetext{
${ }_{7}^{6}$ Publicado originalmente na Revista do Instituto Histórico e Geográfico de Santa Catarina, 3ª Fase, ㄲo 4, 1982-1983.

7 O meio de comunicação com os associados era a revista Skt. Paulusblatt, que passou a ser redigida e editada mensalmente pela própria associação e proporcionava um "material de leitura e informação rico e variado: dicas práticas, informações agrícolas, conselhos de saúde, fomento espiritual, formação cidadã e aconselhamento jurídico" (Rohde, 2012, p. 20).

${ }^{8} \mathrm{~A}$ homogeneidade religiosa era bastante defendida pelo Pe. Max von Lassberg, um dos líderes da Volksverein. Ele argumentava que "a convivência entre protestantes e católicos deveria ser amistosa, mas que os evangélicos deveriam morar numa picada e os católicos numa outra" (Jungblut, 2011, p.71).

${ }^{9}$ O livro de Maria Rohde foi publicado pela primeira vez em 1951, em alemão, na comemoração dos 25 anos de Porto Novo.
} 
A Volksverein teve muitas dificuldades em conseguir uma área para implantar sua colônia. Por um longo tempo, empenhou-se em conseguir terras no Rio Grande do Sul, no entanto, as tentativas falharam. A solução foi migrar para Oeste de Santa Catarina onde as terras eram férteis e baratas, cobertas por densa floresta e afastadas das "influências nefastas do ateísmo e da imoralidade", onde os colonos alemães pudessem preservar sua identidade étnica e sua religiosidade (Werle, 2001).

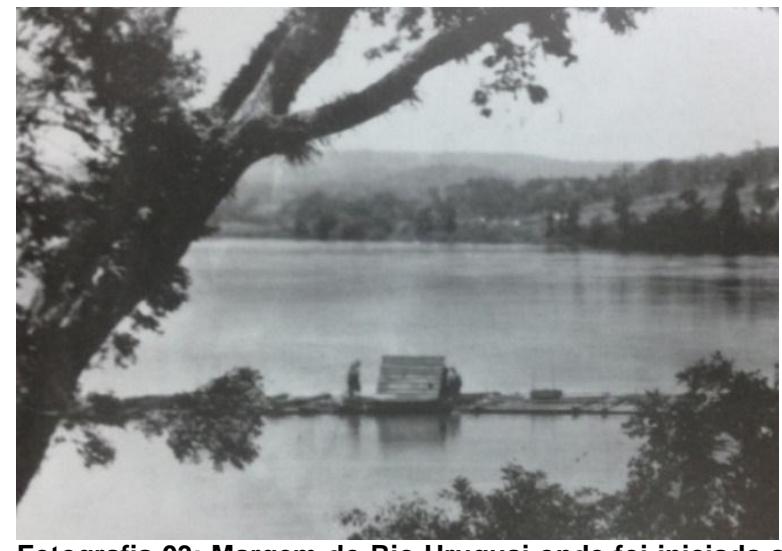

Fotografia 03: Margem do Rio Uruguai onde foi iniciada a colônia de Porto Novo em 1926

Fonte: acervo do Museu Almiro Theobaldo Müller.

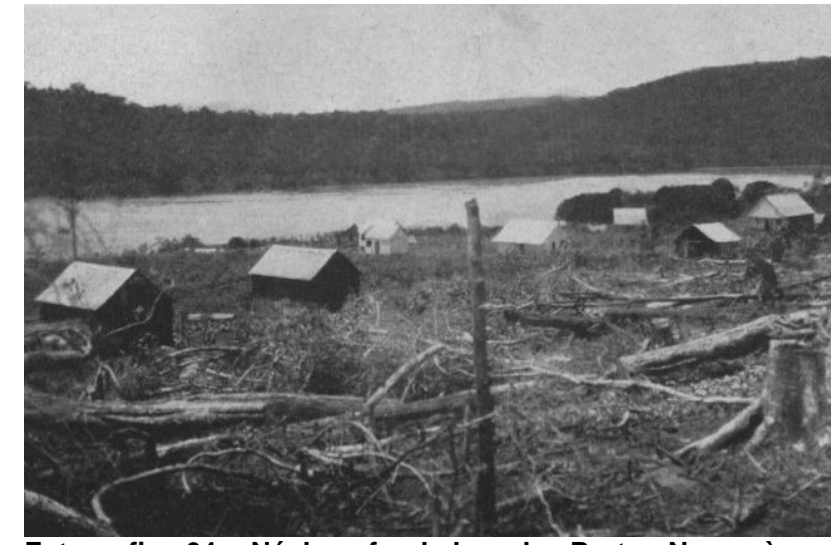

Fotografia 04: Núcleo fundador de Porto Novo às margens do Rio Uruguai por volta de 1927

Fonte: acervo do Museu Almiro Theobaldo Müller.

Naquele período, ao longo da margem direita do rio Uruguai, no extremo oeste catarinense, a vila de Porto Feliz, atual Mondaí, passava por grandes dificuldades devido a uma epidemia de tifo que estagnou a vinda de novos moradores. Como medidas de saneamento e sobrevivência, a empresa colonizadora colocou uma parte da gleba à venda, na fronteira com a Argentina, a qual foi então adquirida pela Volksverein, formando, assim, a Colônia Porto Novo. ${ }^{10}$ Por meio de recursos obtidos junto à Central de Caixas Rurais, a Volksverein adquiriu em torno de 58,5 mil hectares de terras junto à empresa Chapecó-Peperi Ltda., entre os rios Macuco e Pepery-Guaçu, que foram divididos em 2340 lotes (Jungblut, 2015). ${ }^{11}$

Uma vez efetuada a aquisição de terras, a propaganda sobre a Colônia Porto Novo foi iniciada nas colônias velhas do Rio Grande do Sul. Os anúncios na Revista Skt. Paulusblatt destacavam o atendimento religioso e escolar, as terras férteis, o clima favorável, as condições de água, o preço dos lotes e o material humano colonizador, este composto apenas por católicos alemães (Rabuske; Rambo, 2004).

O primeiro grupo interessado no projeto chegou a abril de 1926 e acampou às margens do Rio Uruguai, nas proximidades da atual rodoviária de Itapiranga. ${ }^{12}$ Juntamente com a vinda dos diretores e mostradores de terra da colonizadora, Porto Novo recebeu os primeiros proprietários de terra em maio de 1926 - José Vicente Schneider, José Averbeck e Bernard Bynnemeyer, todos solteiros. As famílias de Pedro Veit, que trabalhava para a Volksverein, de Henrique Pedro Bender e de João Sausen foram as primeiras a integrar o projeto, em julho de 1926. No entanto, alguns meses antes uma família havia se instalado na região. Em 1925, por conta própria, o casal Johann e Margareth Dungersleber e seus 11 filhos vieram diretamente da Alemanha (Jungblut, 2015).

O projeto de colonização nasceu pequeno, mas foi crescendo na medida em que novas glebas foram sendo adquiridas. ${ }^{13}$ Após a divisão das linhas coloniais e da demarcação dos lotes, os pioneiros foram ocupando,

\footnotetext{
${ }^{10}$ Nome escolhido por ser semelhante a Porto Feliz, criada quatro anos antes (Jungblut, 2015).

${ }_{11}$ As Caixas Rurais, caixas de poupança e empréstimo ao modelo Raiffesen ou cooperativas de crédito, foram fundadas em 1902, oferecendo aos colonos condições para que abrissem pequenas poupanças e fizessem financiamentos. Além disso, forneceram recursos para bancar os projetos de colonização e outras obras de importância social (Rambo, 2011).

12 Vale ressaltar que os imigrantes não foram os primeiros moradores da região. Há vestígios da existência de indígenas que habitavam o Alto Uruguai séculos atrás e, além deles, no momento da chegada dos teuto-brasileiros, havia um significativo número de caboclos ocupando as margens do rio. Rohde (2012) descreve que havia "bugres, caboclos e intrusos" quando os primeiros compradores de terra chegaram. "Bugre" era o nome dado aos fragmentos de tribos indígenas que viviam dispersos pela região. "Caboclos", os descentes de aventureiros, exploradores, foragidos da justiça, miscigenados com índios e negros, que viviam à base da agricultura rudimentar, caça e pesca. "Intrusos" eram os antigos extratores de madeira que levavam as toras na forma de balsas pelo rio Uruguai até a Argentina.

${ }^{13} \mathrm{Em}$ suas anotações, Pe. Rick descreve que em 1926 só havia duas casas de agrimensores e a cabana da família Dungersleber, já em 1928, a margem do Uruguai estava povoada numa extensão de 50 quilômetros, de Macuco até a sede (Rabuske; Rambo, 2004).
} 
primeiramente, as terras das margens do Rio Uruguai, e com o passar do tempo, a colonização começou avançar pelo interior, margeando pequenos rios e arroios. Além de lotes rurais, houve também a definição de lotes urbanos com diversas dimensões e que ocupavam as áreas destinadas a sede das comunidades. Foi a partir destes núcleos que surgiram as vilas ou sedes distritais (Hahn, 2005).

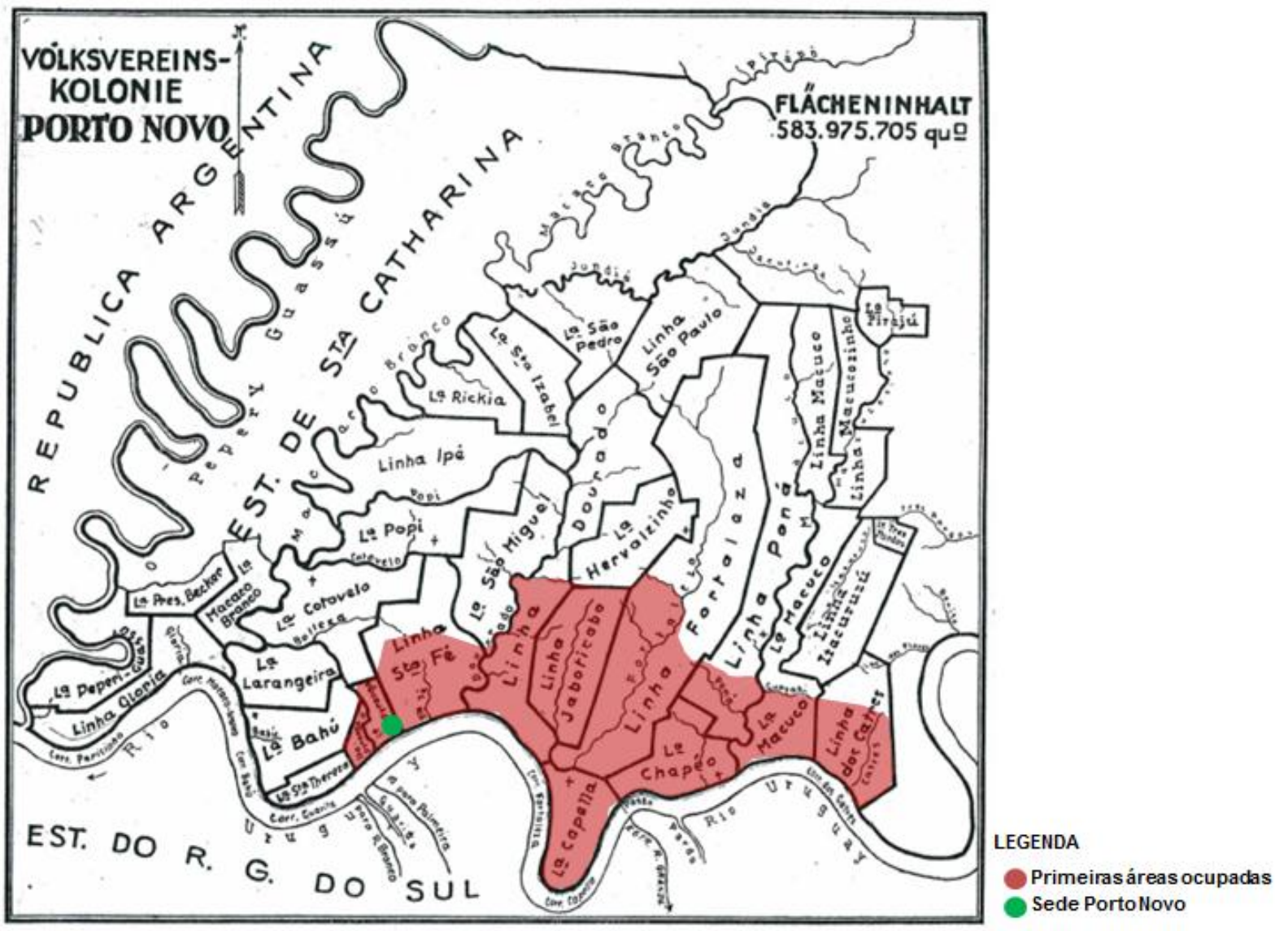

Figura 03: Divisão das comunidades da nova colônia e marcação das primeiras áreas ocupadas Fonte: Jungblut (2011) e Werle (2001) com intervenções dos autores.

A expansão da colonização aconteceu para o norte e para o oeste, conforme observado na figura 03 , tendo o povoamento acontecido gradativamente, de forma natural. Entre 1926 e 1927, as localidades de Catres, Sede Capela, Chapéu, Poná, Macuco, Dourado, Jaboticaba, Fortaleza, Santa Fé Baixa e Sede Porto Novo foram povoadas por cerca de 40 famílias. Nos três anos seguintes, mais moradores chegaram às comunidades já existentes e outras foram formadas, dentre elas: Baú, Laranjeira, Popi, Santa Cruz, Cotovelo, Ervalzinho, Beleza, Jaboticaba. De 1931 e 1939, o avanço territorial seguiu por Linha Presidente Becker $^{14}$, São Joao, Glória e Cabeceira do Dourado - atual Beato Roque.

\section{A INFLUËNCIA GERMÂNICA NA FORMAÇÃO DE CIDADES DO SUL DO BRASIL}

Logo após a proclamação da Independência brasileira, o governo apontou a necessidade de "colonizar" novas regiões do país, os vazios demográficos e as regiões de fronteira, por brancos não-portugueses. Desse modo, oferecendo diversas vantagens buscou viabilizar a vinda de imigrantes europeus, os quais, precedidos por seus descendentes, ao longo de mais de cem anos, desempenharam um importante papel no desenvolvimento da região Sul do Brasil (Roche, 1969).

A colônia de São Leopoldo, no Rio Grande do Sul, marca efetivamente o início do processo de colonização das terras devolutas do sul. Outras três colônias fundadas até 1930, ano em que se encerra a primeira fase

\footnotetext{
${ }^{14}$ Porto Novo recebeu imigrantes vindos diretamente da Alemanha, os Deutschländer. A eles foi destinada a Linha Presidente Becker que, geograficamente, localiza-se próximo à fronteira da Argentina, e que, naquele período, ainda não estava loteada. Foi nesta mesma comunidade que, em 1978, surgiu a Oktoberfest, festa que dá à Itapiranga o título de Berço Nacional da Oktoberfest (Mayer, 2016).
} 
de colonização devido à falta de recursos do governo imperial, foram São Pedro de Alcântara e Mafra, ambas em Santa Catarina, e Rio Negro no Paraná (Gregory, 2014). O projeto, retomado em 1945, resultou em novos assentamentos no Rio Grande do Sul, seguindo pelo vale do rio Dos Sinos e, posteriormente, distribuindo-se pelo interior do estado por meio de colonizações provinciais e particulares, e em Santa Catarina, no vale do Itajaí, também por iniciativas particulares (Roche, 1969).

No Rio Grande do Sul, Roche (1969) destaca que apesar das cidades colonizadas por alemães terem sido inicialmente pequenas e voltadas para a população rural, os colonos alemães impuseram seu domínio e transformaram a paisagem, caracterizando como elementos reveladores a casa, o habitat rural e a povoação. Para fins da presente pesquisa, analisaremos as características elencadas do habitat rural e das povoações.

O habitat rural é caracterizado como "habitat em fileira" onde os lotes de terra de 25 hectares em média foram distribuídos paralelos um ao outro ao longo de picadas, formando assim lotes isolados. Weimer (1983) ressalta que esses lotes eram raros na Alemanha, mas foi o modelo de ocupação do solo do imigrante no Brasil, pois já estavam previamente demarcados, caracterizando assim o aspecto rural da ocupação do solo. Dessa forma, pela configuração dispersa no território, eram necessários pontos de encontro que proporcionassem a integração dos moradores e a participação destes na vida em comunidade. Assim, à beira das picadas ou no lote de um dos colonos surgiam a capela, a escola, as casas comerciais e o salão de festas. (Roche, 1969).

A povoação, por sua vez, surgiu a partir da aproximação das casas nos lotes laterais e passou a agregar o centro administrativo, comercial, artesanal, escolar, religioso e social da picada, recebendo o nome de Waldhufendorfen ou Strassendorfen - ocupações originadas a partir de uma rua -, ou então de Stadtplatz, nome genérico dado pelos colonos (Roche, 1969).

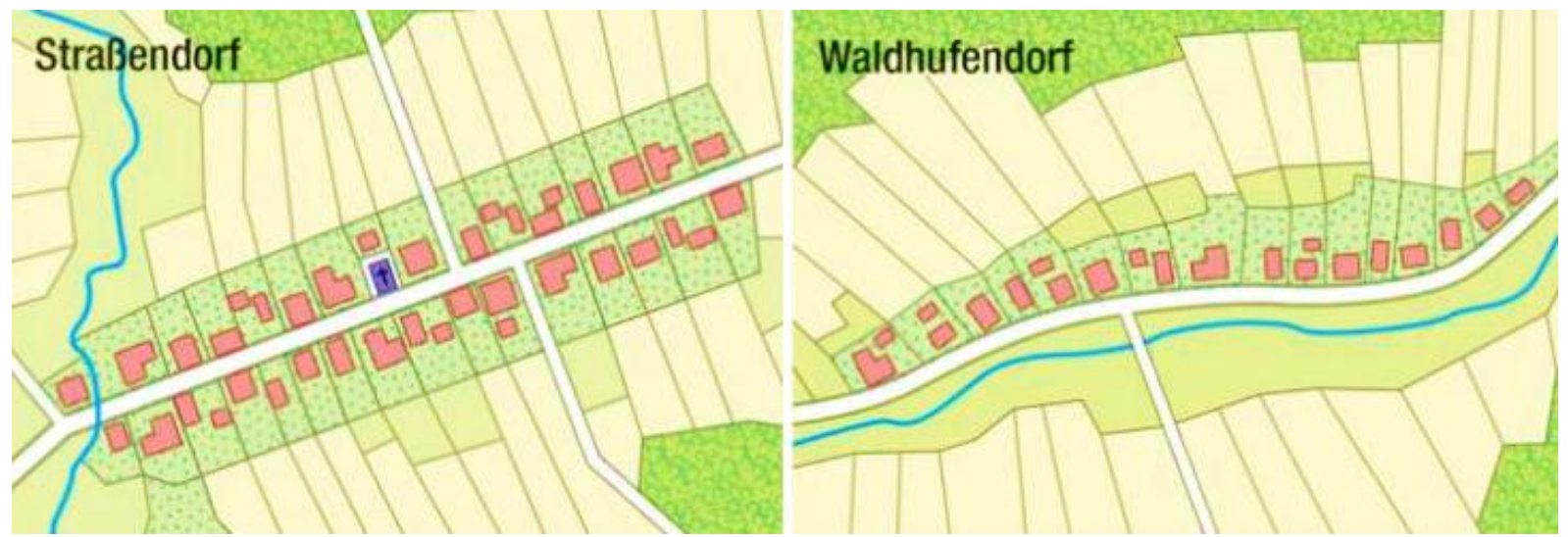

Figura 04: Strassendorfen e Waldhufendorfen - povoações originadas a partir de uma rua

Fonte: Diercke Welatlas (2016, disponível em: http://www.diercke.de/content/dorfformen-978-3-14-100800-5-77-5-1).

A Strassendorfen é a planta que caracteriza a grande maioria das cidades pequenas colonizadas por alemães e seus descendentes, possuindo casas em ambos os lados da rua principal e possibilitando a abertura de ruas paralelas e perpendiculares a ela. Neste contexto, Roche (1969) apresenta diversos exemplos de povoações com as características citadas, como Cadeado (atual sede de um distrito de ljuí) onde a partir da rua principal surgiram outras seis ruas perpendiculares e duas paralelas, esboçando um tabuleiro de xadrez - similar ao plano de urbanização corrente no Rio Grande do Sul naquele período.

Outro aspecto importante levantado por Roche (1969) é a implantação das colônias nas proximidades de um curso d'água, para existir um porto fluvial, ou de vias de comunicação, como estradas e linhas férreas. Esse é o caso das velhas colônias gaúchas, como São Leopoldo e Novo Hamburgo, no Vale do Rio dos Sinos. Ambas são Strassendorfen nas quais, primeiro o rio, depois a via férrea e então a estrada de rodagem, caracterizaram-se como elementos essenciais para o desenvolvimento.

Em Santa Catarina, as principais colônias de descendência alemã foram fundadas por iniciativa particular, destacando-se Blumenau e Joinville. Peluso Jr. (1991), ao estudar as diferenças entre o traçado urbano das cidades catarinenses, atribuiu características à cultura de cada etnia formadora das colônias - sintetizadas nas figuras 05 e 06 -, constatando que os núcleos de origem portuguesa, como Florianópolis e Lages, tiveram sua formação a partir da praça central e da igreja, sendo que esta ocupa lugar de evidência como 
instituição política, e, os núcleos de origem alemã, Blumenau e Joinville, partiram da rua comercial e foram se adaptando ao relevo encontrado, caracterizando-se pelas instituições econômicas.

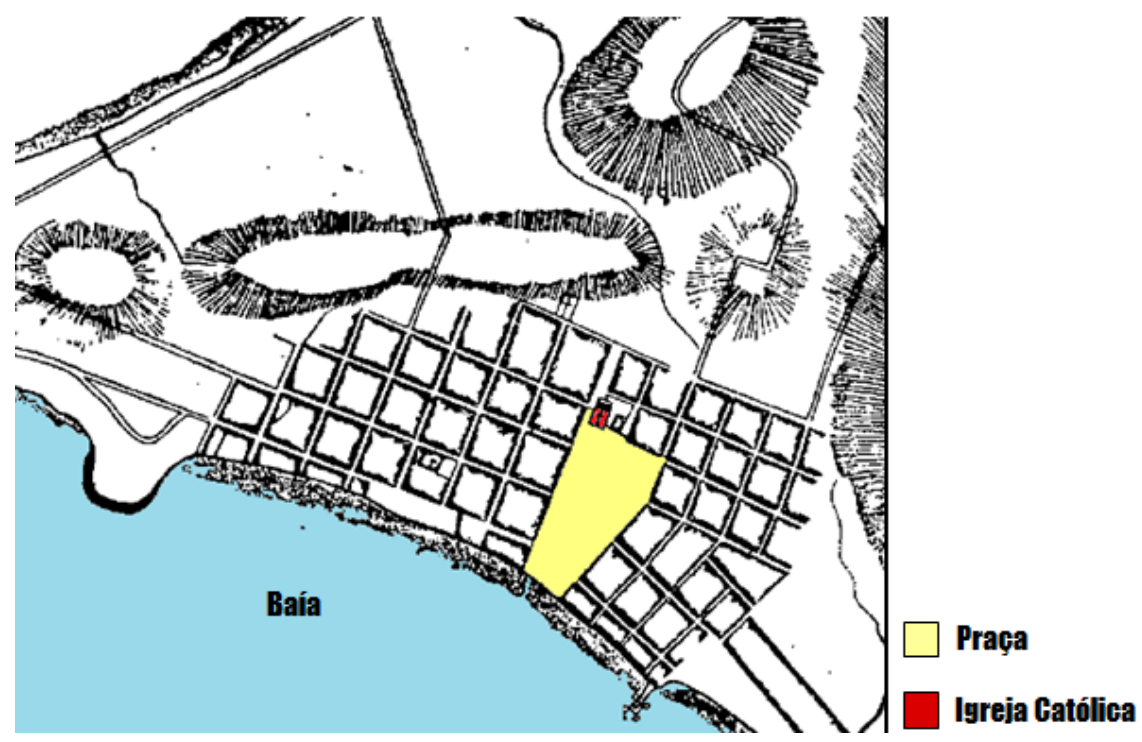

Figura 05: Florianópolis, cidade de origem portuguesa - formação do núcleo a partir da praça e da igreja Fonte: Peluso Jr. (1991, p. 359) com intervenções dos autores.

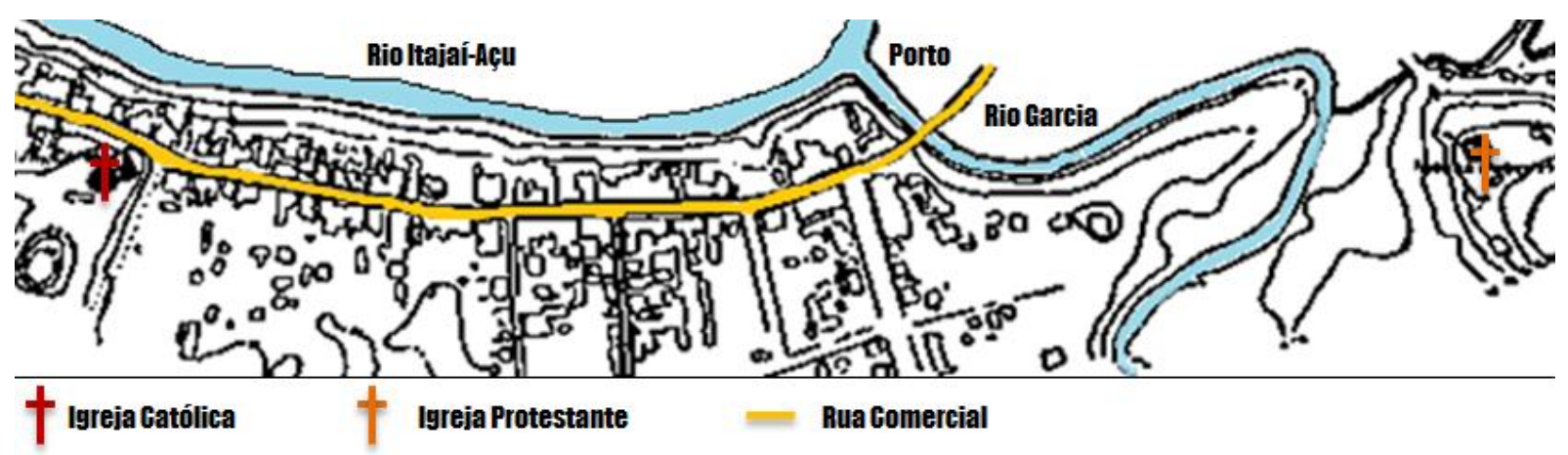

Figura 06: Blumenau, cidade de origem alemã - formação do núcleo a partir da rua comercial Fonte: Peluso Jr. (1991, p. 376) com intervenções dos autores.

O plano das cidades alemãs descritas pelo urbanista Bernoulli e estudado por Peluso Jr. (1991, p. 392) evidencia que as cidades deveriam estar protegidas por uma montanha ou por um rio e ter um mercado e uma rua principal, além disso, a igreja e o cemitério deveriam estar apartados do tráfego, "mas de maneira que a nave maior e o campanário, emergindo do alto das casas, dominem a praça principal".

Blumenau se desenvolveu entre o rio Itajaí e a montanha, próximo ao porto fluvial, entre a foz do ribeirão Garcia e a foz do ribeirão da Velha - Stadtpltaz, e ao longo de uma rua principal, sendo que as ruas posteriormente abertas estavam paralelas ou perpendiculares a ela, adaptando-se ao relevo. Os mesmos aspectos podem ser encontrados em Joinville, cujo elemento gerador foi o ribeirão Matias, e em ambas, os sítios das igrejas católicas não tiveram relevância no plano urbano, pois estavam afastados do núcleo principal (Pelulo Jr, 1991).

Além do elemento da rua comercial, Sierbert $(1999$, p. 41) levantou a questão da estrutura fundiária das colônias alemãs, na qual a demarcação dos lotes "foi determinada pela necessidade de todos os colonos terem acesso à água, necessária ao cultivo e como meio de transporte". Em Blumenau, essa característica, associada à topografia acidentada, gerou lotes estreitos e compridos, distribuídos paralelamente entre si e perpendicularmente aos cursos d'água e às picadas abertas, conforme apresentado na figura 07 . Em pontos estratégicos alguns lotes foram reservados para a construção de escolas e igrejas a fim de formar pequenos núcleos urbanos. 
Apesar de se tratar de lotes isolados, apresentados por Roche (1969) e Weimer (1983), Siebert (1999) ressalta que esse sistema representou uma menor distância entre os colonos, garantindo, além de segurança contra possíveis ataques indígenas e de animas selvagens, a formação do espírito comunitário em uma sociedade coesa com fortes laços culturais.

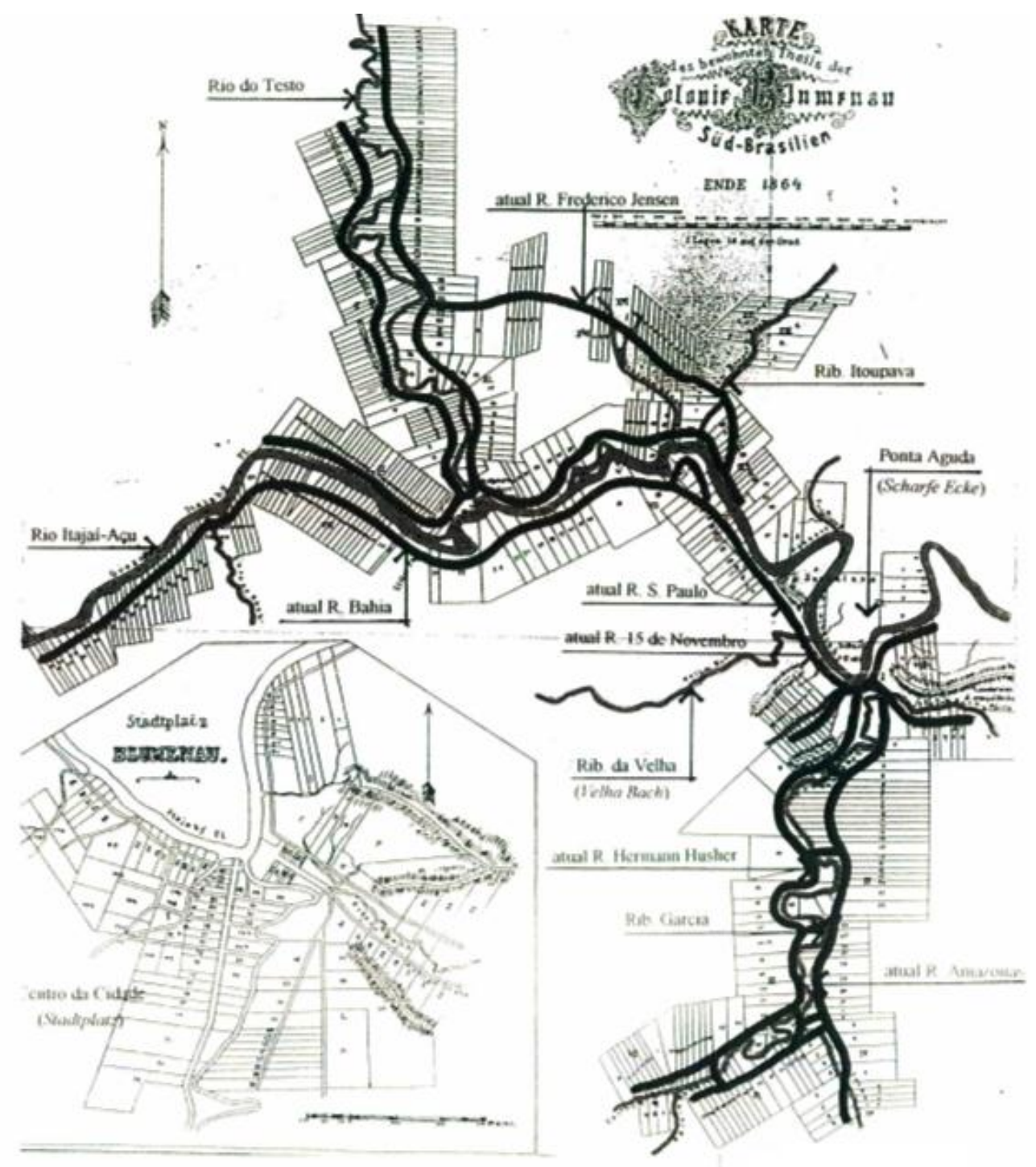

Figura 07: Lotes coloniais de Blumenau em 1964

Fonte: Siebert (1999, p. 54).

Os aspectos apresentados demonstram o aparecimento e a repetição de planos urbanos que podem ser associados a certos grupos de origem comum. Portanto, além da grande influência das condições morfológicas e geográficas dos sítios de implantação das colônias, merece destaque a influência cultural alemã dos grupos formadores dessas colônias, pois como afirma Peluso Jr (1991, p. 356), "tomando-se cidades de uma mesma cultura, pode julgar-se que as diversidades são atribuídas às diferenças geográficas, enquanto as semelhanças o são ao equipamento cultural comum".

\section{CARACTERÍSTICAS DA FORMAÇÃO E EVOLUÇÃO URBANA DE ITAPIRANGA (SC)}

A forma urbana das cidades teuto-brasileiras do sul do Brasil apresenta diversas singularidades. Nem sempre são encontradas as mesmas configurações morfológicas do sítio, mas a forma de implantação seguiu características comuns. Em Itapiranga, objeto de estudo da presente pesquisa, encontramos algumas dessas características apresentadas que tiveram significativa influência sobre a forma da cidade e a evolução do traçado urbano. 
Como primeiro elemento, destacamos a implantação geral da colônia inicialmente ao longo de um importante curso d'água do oeste catarinense, o rio Uruguai, que apresenta largura entre 500 e 630 metros na altura de Itapiranga, e o avanço pelo interior margeando outros cursos d'água de menor expressão. A distribuição dos lotes buscou possibilitar que todos os colonos tivessem acesso à água para a utilização doméstica e para o cultivo, e, da mesma forma, facilitando a comunicação da colônia com outras cidades e com o Rio Grande do Sul, por meio da navegação fluvial. ${ }^{15}$

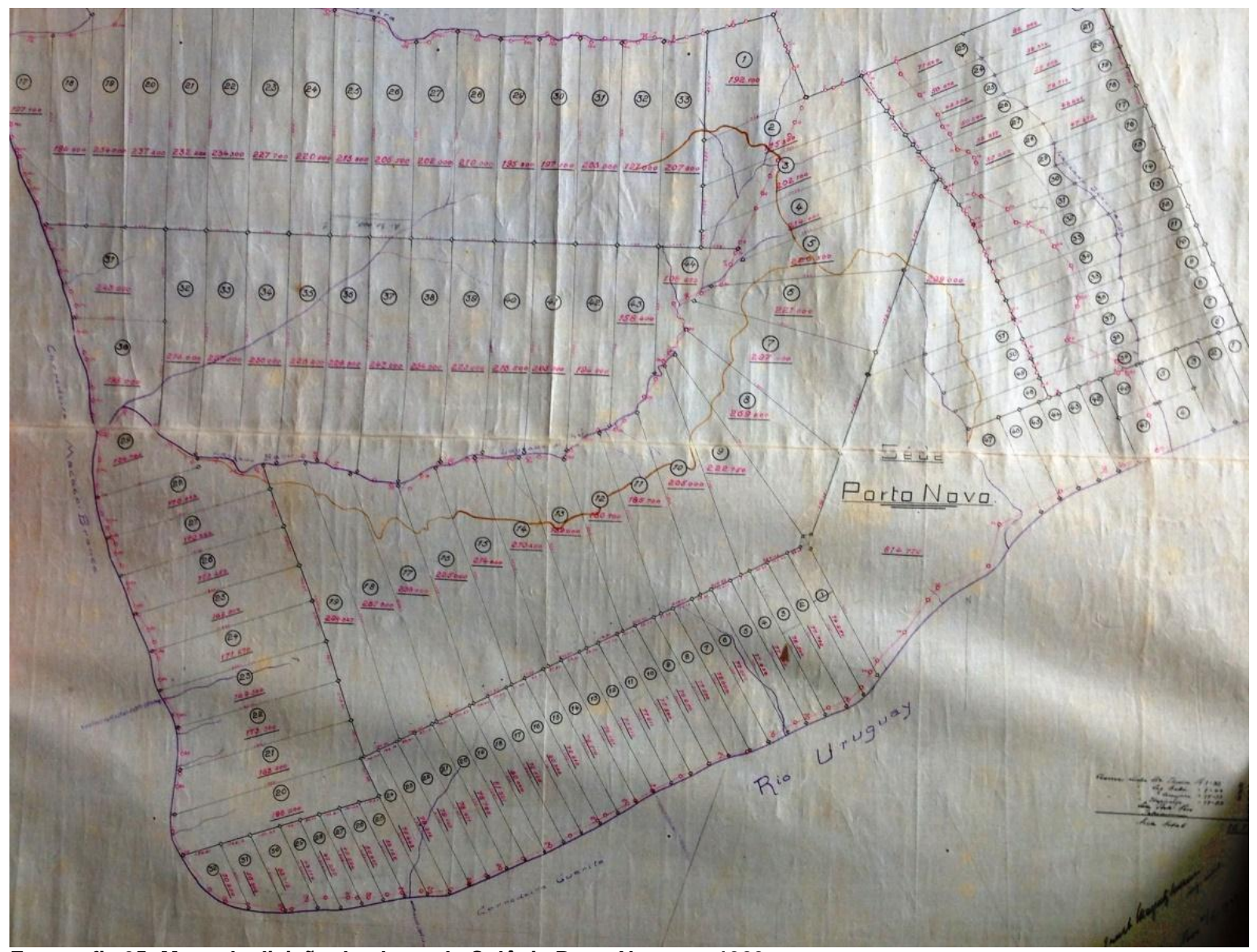

Fotografia 05: Mapa da divisão dos lotes da Colônia Porto Novo em 1929

Fonte: acervo de Prefeitura Municipal de Itapiranga.

Neste contexto, caracterizamos também o processo de divisão dos lotes coloniais. Em geral estreitos e compridos, os lotes foram demarcados de modo que abrangessem de 25 a 36 hectares e distribuídos paralelamente um ao outro e perpendicularmente às linhas coloniais, possibilitando que uma única estrada servisse a muitos lotes. Na fotografia 05, retirada de uma das cartografias disponíveis no acervo da Prefeitura Municipal de Itapiranga, pode ser percebida a forma característica de constituição e distribuição dos lotes coloniais, estreitos e compridos, buscando, na medida do possível, o acesso aos cursos d'água. Já a cartografia representada na figura 08 , reproduzida originalmente no livro "Porto Novo: um documentário histórico" do historiador local Roque Jungblut (2011), foi incluída em nosso estudo por trazer uma representação geral de como seria a distribuição dos lotes coloniais em toda a então Colônia Porto Novo, podendo ser observada a característica predominante dos lotes. As áreas em amarelo mais escuro, rosa e azul representam os atuais municípios de Itapiranga, Tunápolis e São João do Oeste, respectivamente, e, a área em amarelo claro são glebas que hoje pertencem ao município de Mondaí.

\footnotetext{
${ }^{15}$ Os nomes dos mananciais de água já eram conhecidos dos caboclos e balseiros quando os agrimensores chegaram, porém, estes foram instruídos a nomear qualquer acidente geográfico com termos indígenas. O agrimensor Ernst Maynthusen era o único que falava um pouco de tupi-guarani e nomeou alguns córregos. Em Porto Feliz, a um regato deu o nome de Mondaí (Mondá = ladrão e $Y=$ água) e em Porto Novo, ao regato na entrada da cidade deu o nome de Itapiranga (Itá = pedra e Piranga = vermelha). Em 1929, na vista do então governador catarinense Adolfo Konder, os termos indígenas foram utilizadas para renomear as duas colônias (Jungblut, 2011, p. 137).
} 


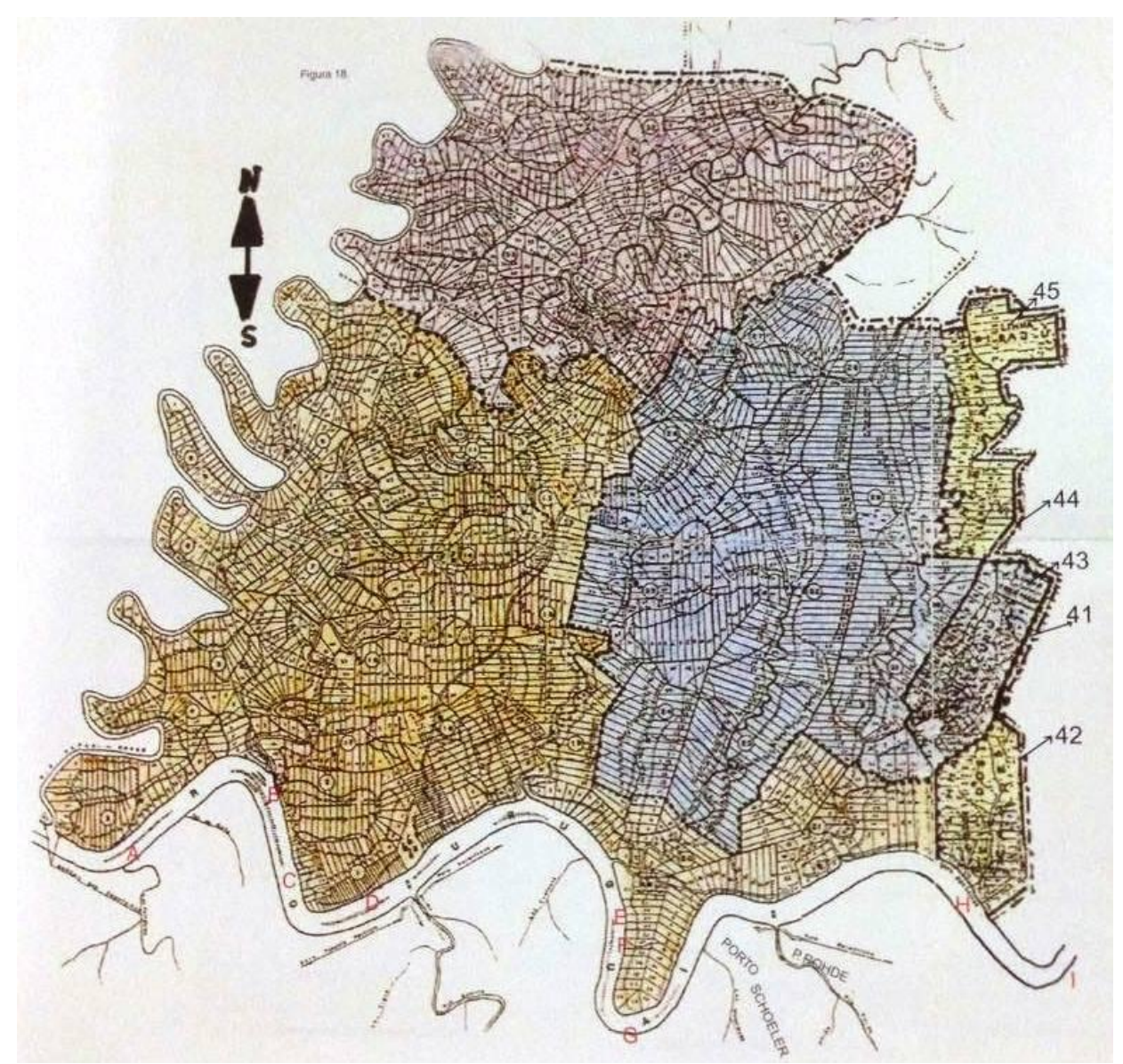

Figura 08: Divisão completa dos lotes coloniais da Colônia Porto Novo

Fonte: Jungblut (2011).

A estrutura fundiária ideal para a colônia deveria fornecer as condições básicas para facilitar a integração dos moradores e a participação destes na vida em comunidade. Além dos lotes coloniais destinados às propriedades rurais, houve também a definição de lotes urbanos com diversas dimensões e que ocupavam as áreas destinadas à sede das comunidades. Foi a partir destes núcleos que surgiram as vilas ou sedes distritais, onde se encontrava, em geral, a igreja, a escola, uma venda e um salão de festas. Alguns desses elementos ainda compõe o núcleo das comunidades interioranas.

Abrigando a sede da diretoria oficial da colonização, Sede Porto Novo desenvolveu-se como núcleo urbano. ${ }^{16}$ Conforme descrições encontradas na bibliografia consultada, o núcleo fundador de Itapiranga foi iniciado no entorno da atual Praça dos Imigrantes, nas imediações do atual Terminal Rodoviário. Jungblut (2011, p. 78) descreve que "em 1926, foram feitas as seguintes construções na Sede Porto Novo: Casa Provisória do Imigrante, na futura Praça das Bandeiras ou Prefeitura; residência de José Aloísio Franzen e sede provisória da administração de Porto Novo, onde hoje está o prédio do Fórum; dia 22 de novembro de 1926, foi preparado o terreno onde nos meses seguintes foi construída a primeira igreja-escola e em 1932 ao lado oposto do prédio da Caixa Rural, na Praça das Bandeiras. Em 1927, foi construída a Cada da Administração, em frente ao futuro Clube Imigrantes". As localizações dos elementos arquitetônicos citados que compuseram a paisagem urbana do período fundacional estão representadas na figura 09. Esse núcleo fundador, como local de gênese da cidade, pode ser considerado a Stadtzplatz de Itapiranga, embora esse nome não figure dentre os estudos já realizados acerca da história de formação da Colônia Porto Novo

\footnotetext{
${ }^{16}$ Sede Capela e Sede Porto Novo estavam em pé de igualdade e protagonizaram uma disputa pela hegemonia em Itapiranga. Pe. Rick relata que na segunda surgiu uma "mesquinha política local" que se opunha à colonização da primeira, na parte superior e mais distante. No entanto, a concorrência se seguiu e apesar de todos os investimentos feitos em Sede Capela, Sede Porto Novo se desenvolveu como núcleo urbano (JUNGBLUT, 2011).
} 


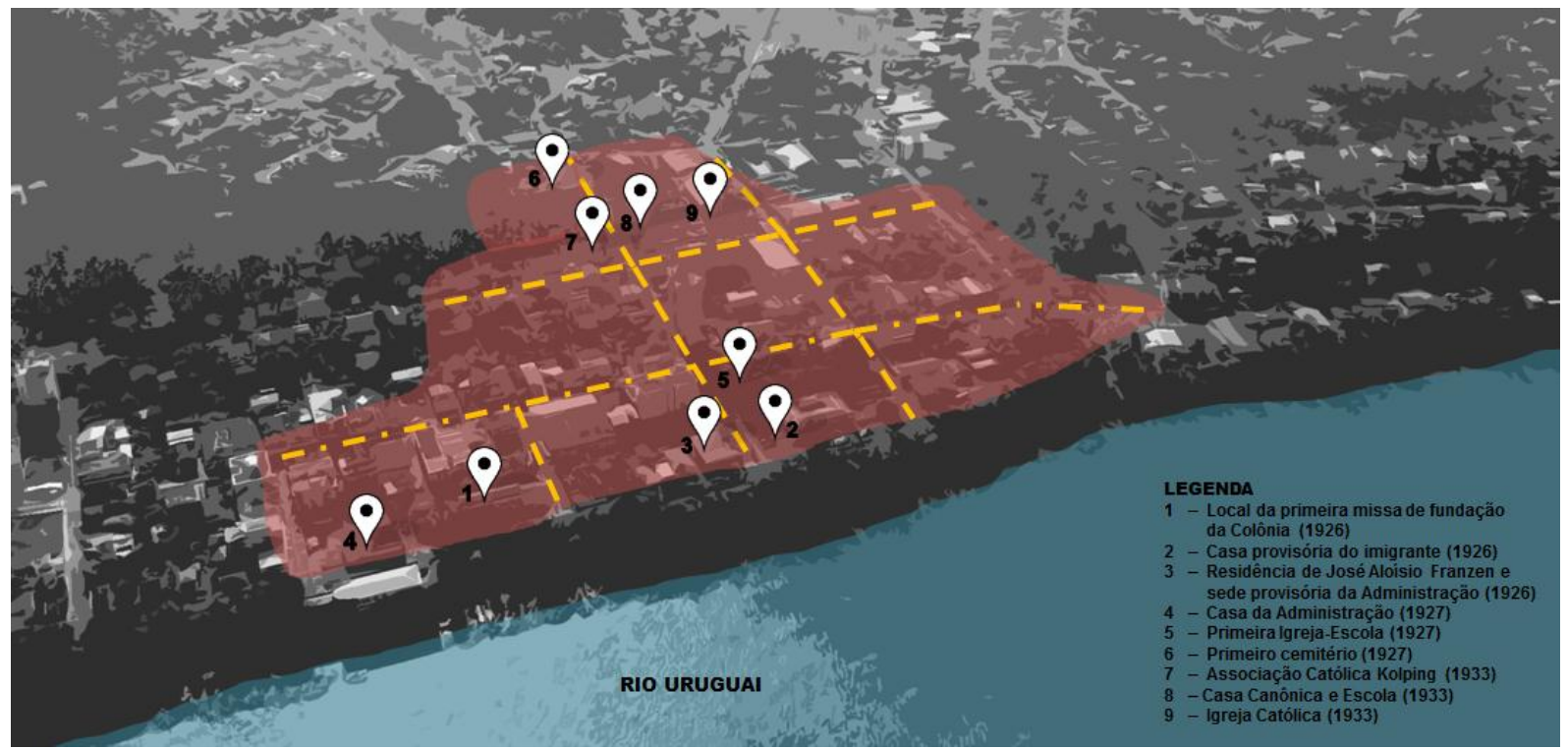

Figura 09: Local das primeiras construções no núcleo urbano

Fonte: elaborado pelos autores com base em dados fornecidos por Jungblut (2011).

Outros elementos que compuseram a paisagem urbana do núcleo fundacional e ainda permanecem são a Associação Católica Kolping, inicialmente denominada Grêmio Católico de Artífices, e a Casa Canônica. Ambas foram construídas no ano de 1933 e se destacam na paisagem pela arquitetura diferenciada do seu entorno. A primeira se trata de uma edificação originalmente construída em madeira, distribuída em dois pavimentos e com telhado chalé de duas águas, porém, intervenções recentes em alvenaria resultaram na adição de um pavimento. O Kolping servia como local de auxílio aos novos moradores que chegavam e, conforme destaca Werle (2007), era um importante meio de associativismo, ajuda mútua e manutenção dos valores religiosos e da cultura alemã. Já a Casa Canônica, destaca-se por ser construída em alvenaria, distribuída em dois pavimentos, com varanda e sacada na parte frontal e telhado de duas águas com mansardas em ambos os lados. Desde 1979, a edificação abriga o Museu Comunitário Almiro Theobaldo Müller que preserva peças, documentos e fotografias relacionados com a colonização iniciada pela Volksverein e também preserva vestígios de sambaquis objetos de cerâmica, adornos, pedra lascada e pedra polida, datados de mil a dois mil anos atrás.
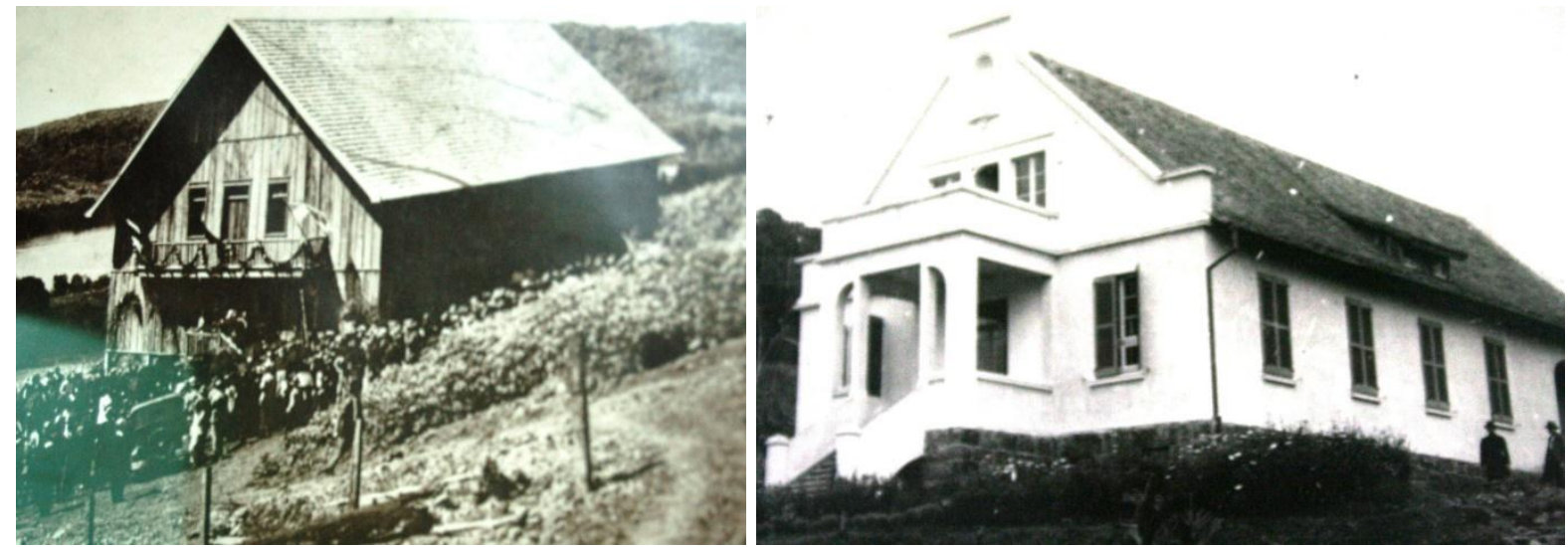

Fotografias 06 e 07: Associação Católica Kolping e Casa Canônica na década de trinta

Fonte: acervo do Museu Almiro Theobaldo Müller. 


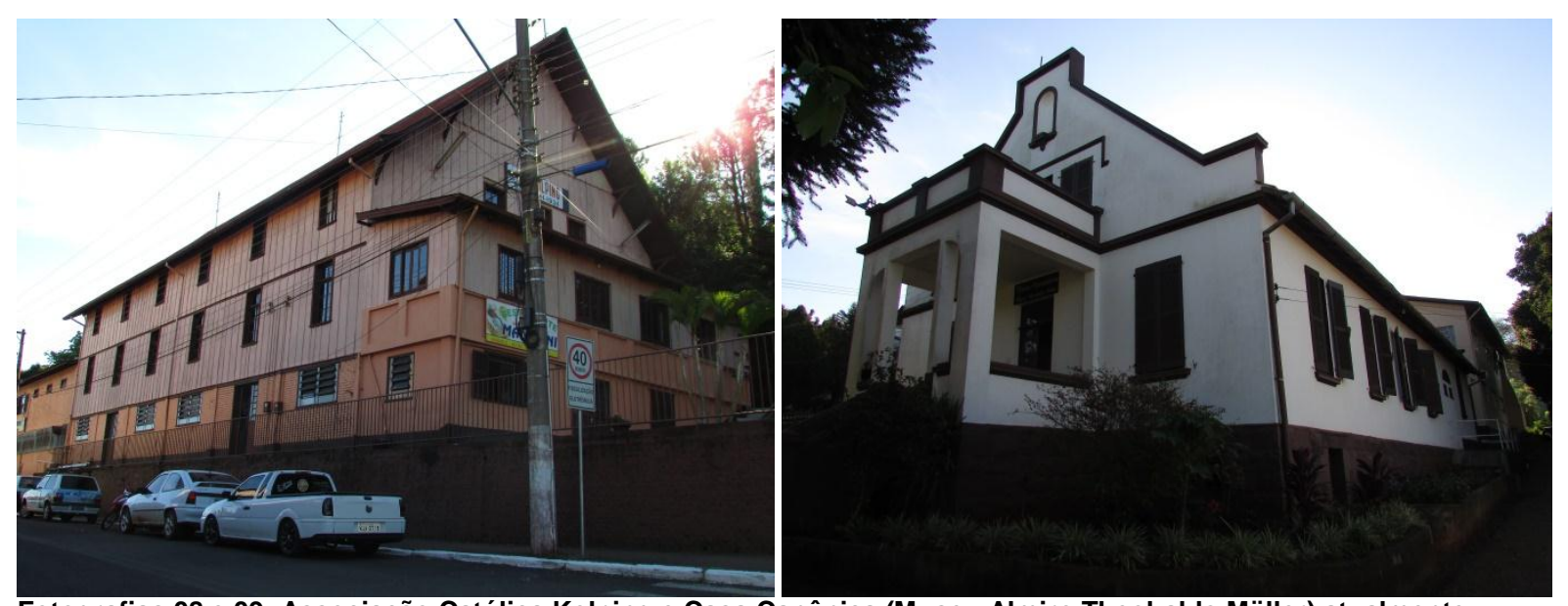

Fotografias 08 e 09: Associação Católica Kolping e Casa Canônica (Museu Almiro Theobaldo Müller) atualmente Fonte: os autores (2017).

Em 1930, Porto Novo possuía 822 habitantes, sendo que na sede da colônia havia 32 lotes urbanos e 31 lotes rurais, destes 16 lotes estavam ocupados por 19 famílias, somando 125 moradores (Rambo, 2011). Apesar da estrutura econômica inicial ter se voltado para a agricultura familiar de subsistência, as constantes chegadas de novos imigrantes com formações profissionais diversas contribuíram para 0 estabelecimento e o desenvolvimento do comércio.

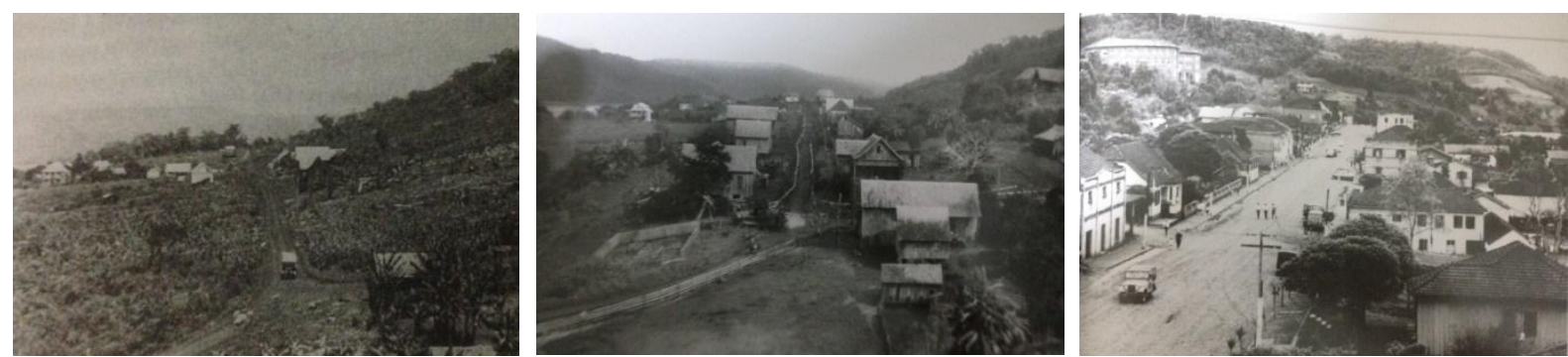

Fotografias 10, 11 e 12: Rua principal nos anos de 1927, 1935 e 1955, respectivamente

Fonte: acervo do Museu Almiro Theobaldo Müller.
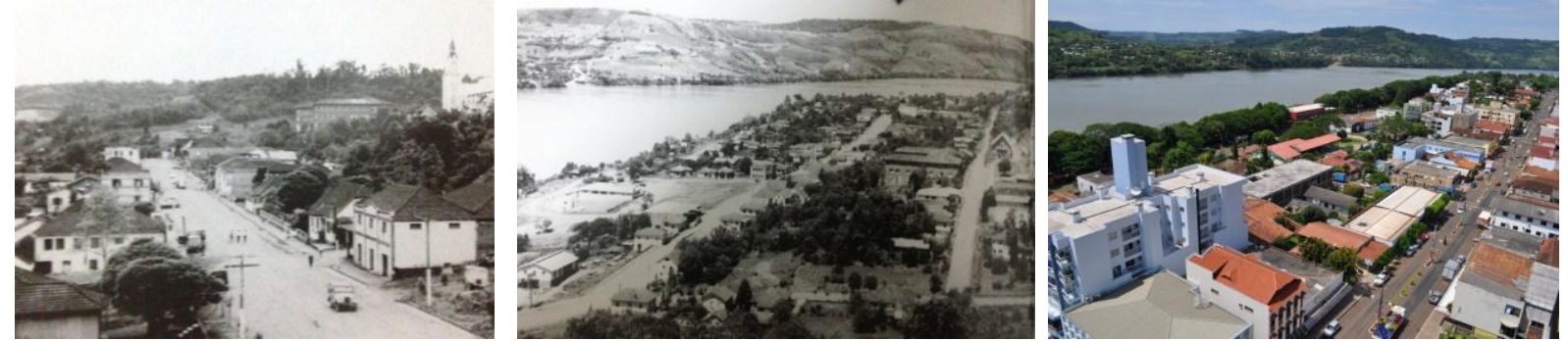

Fotografias 13, 14 e 15: Rua principal nos anos de 1955, 1970 e 2016, respectivamente (futura Rua do Comércio)

Fonte: acervo do Museu Almiro Theobaldo Müller.

Considerando que a Stadtplatz tenha passado a servir como centro administrativo, comercial, escolar, religioso e social da colônia, a partir da análise das fotografias dos primeiros anos de colonização e desenvolvimento da colônia (fotografias 10,11,12,13, 14 e 15), pode-se afirmar que, em Itapiranga, o elemento gerador da forma urbana também foi uma rua, linear e paralela ao longo do rio (figura 09) configurando assim uma Strassendorfen -, cujo papel foi de extrema importância na ordenação do plano urbano, no qual as novas ruas abertas foram sempre paralelas ou perpendiculares a ela. A rua principal atual Rua do Comércio - recebeu acima uma rua paralela na década de trinta, a Rua São Bonifácio, e na década de setenta, outra foi aberta junto ao rio Uruguai como continuação da Rodovia SC 472, configurando a Avenida Uruguai e a Avenida Beira-Rio.

Outro elemento de destaque no traçado urbano é o plano ortogonal na conformação das ruas e quadras abertas a partir da rua principal. Ao que parece essa característica, apesar de estar presente em outras cidades de colonização alemã, não está relacionada com a cultura dos novos colonizadores, mas sim ao fato de haver certa predominância da implantação de planos urbanos de malha quadriculada por todo o Brasil durante o período correspondente à implantação de Itapiranga. 


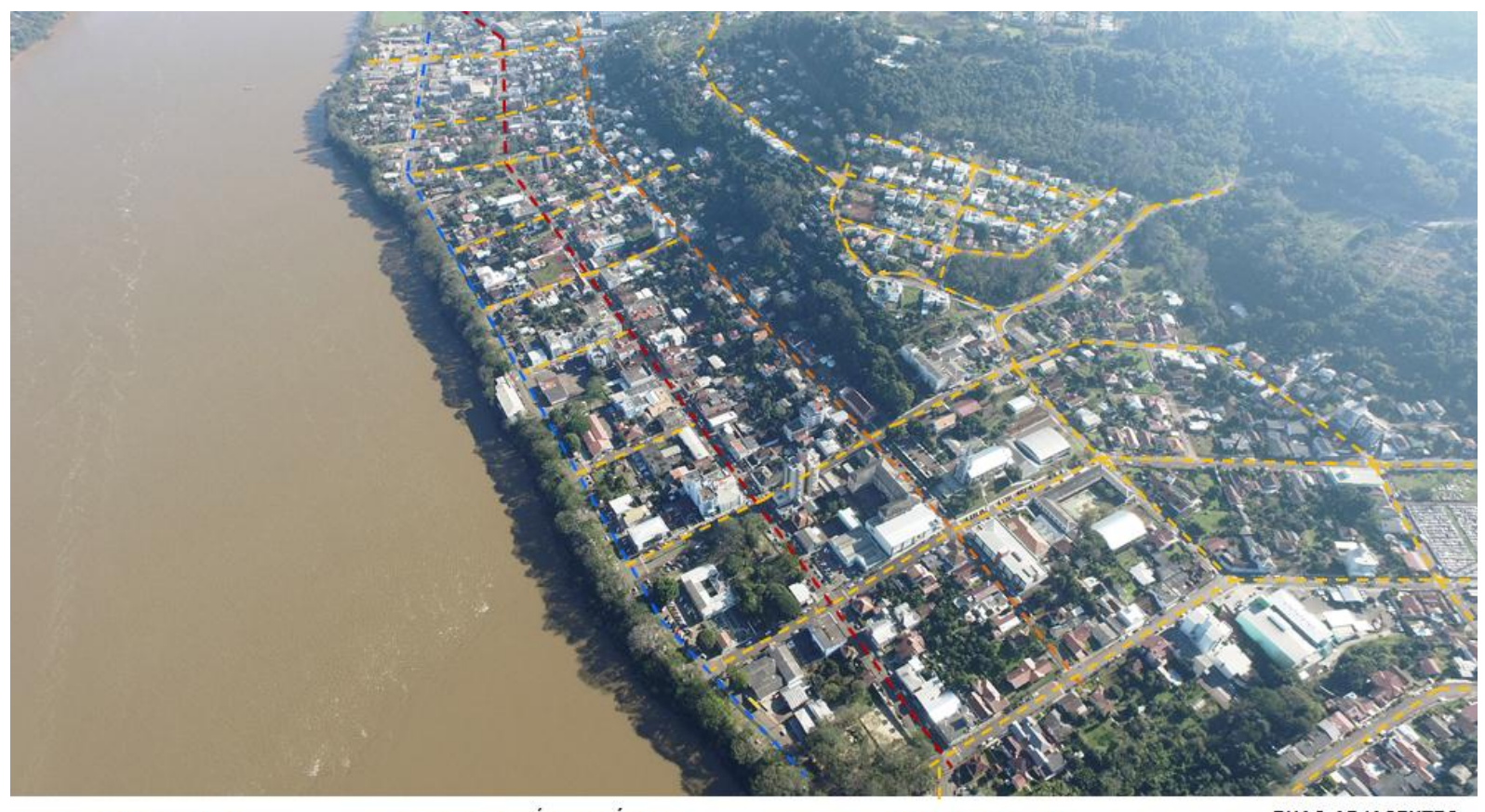

- - - RUA COMERCIAL

- - - R. JOSÉ BONIFÁCIO

$---\quad$ AVENIDA URUGUAI

- - RUAS ADJACENTES

Fotografia 16: Traçado ortogonal no núcleo urbano atual de Itapiranga

Fonte: os autores (2016).

Não podemos deixar de considerar que diferentemente do que pode ser encontrado em outras cidades com características alemãs, nas quais a igreja não influenciava no espaço urbano, em Itapiranga, ela teve um importante papel, pois a organização da colônia estava sob comando de padres jesuítas e, consequentemente, subordinada aos preceitos católicos. Assim, conforme descrições da época, a primeira capela construída no núcleo urbano estava nas imediações da rua comercial. No entanto, a Igreja Matriz, construída em 1951 (e existente até o momento), com a singeleza de uma única torre sineira e duas águas, corresponde à orientação do antigo plano alemão, encontrando-se afastada do centro urbano, mas conforme apontado por Bernoulli, "emergindo do alto das casas" e dominando a praça principal, característica que pode ser observada nas fotografias 17 e 18. É importante ressaltar que, apesar da ênfase dada sobre a Igreja, não houve a criação da praça.

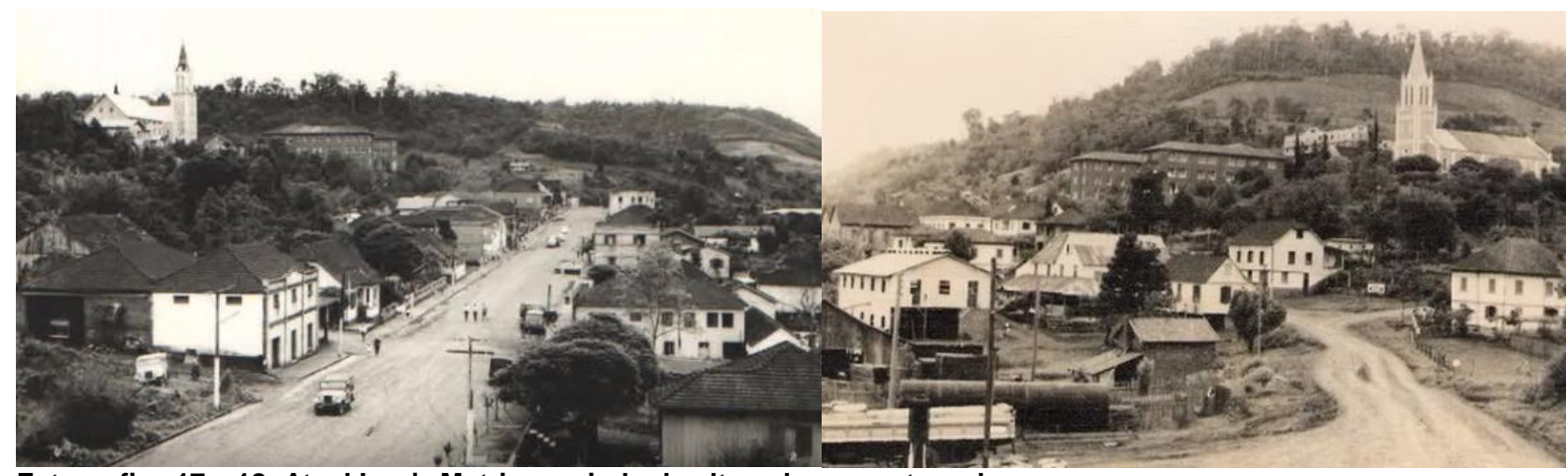

Fotografias 17 e 18: Atual Igreja Matriz surgindo do alto sobre o centro urbano

Fonte: acervo do Museu Almiro Theobaldo Müller.

Com o passar do tempo, a colônia foi evoluindo seu núcleo urbano, transformando-se, oficialmente, em cidade. O crescimento político e econômico do distrito de Itapiranga durante as suas primeiras décadas de colonização possibilitou o desmembramento de Itapiranga de Chapecó no ano de 1954, o que foi essencial para a organização da administração municipal, para o progresso econômico e social e para a evolução urbana do município. 


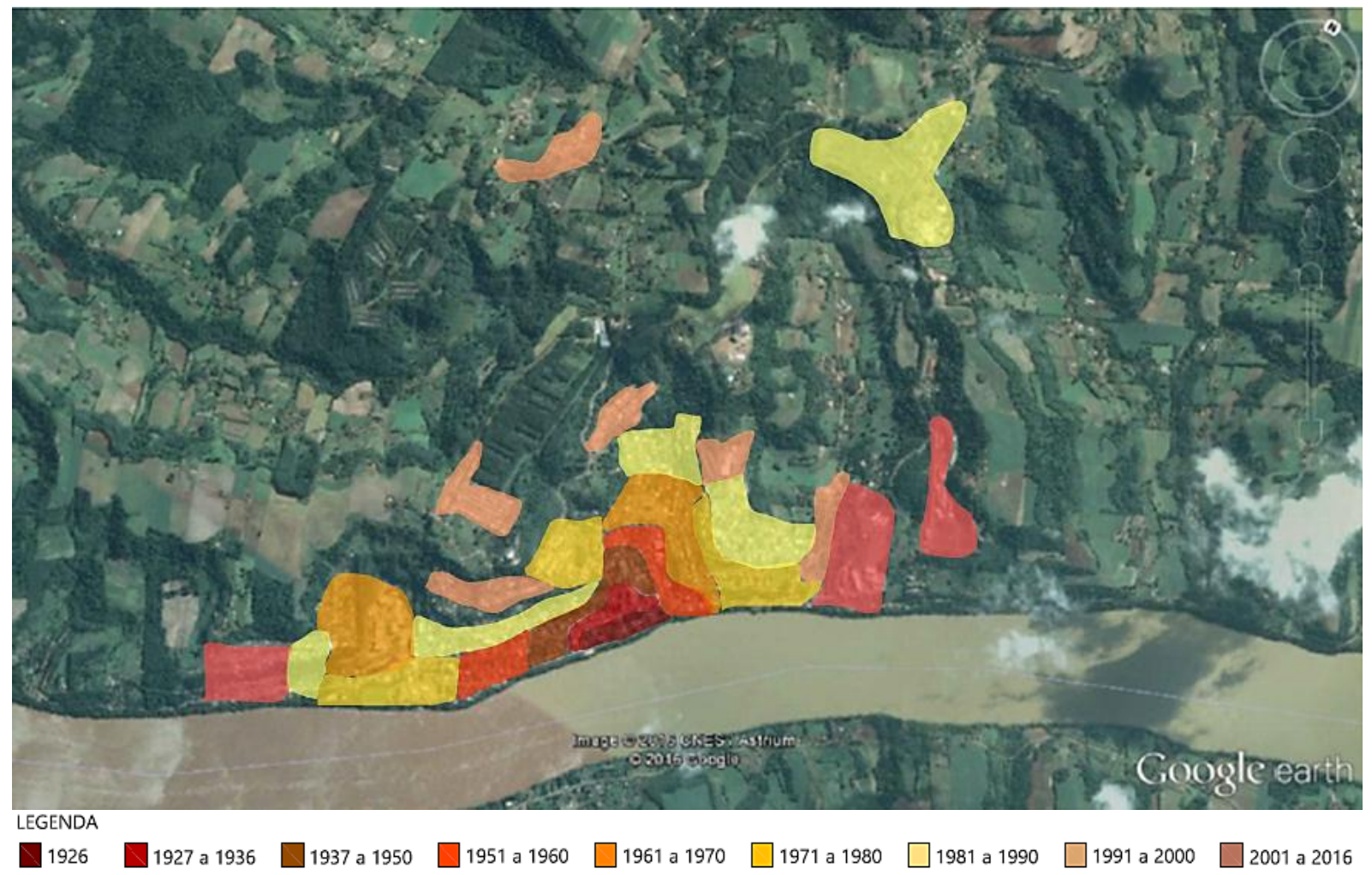

Figura 10: Mapeamento da evolução urbana do município de Itapiranga

Fonte: elaborado pelos autores com base em dados históricos e na legislação municipal.

A expansão da malha urbana de Itapiranga apresenta uma relação bastante estreita com sua trajetória econômica. $O$ isolamento geográfico e a dependência de atividades econômicas rudimentares representavam barreiras para o crescimento. Então, no ano de 1962, foi elaborado e executado um plano de desenvolvimento econômico para o município, que dentre as ações previstas, buscou a realização de obras de infraestrutura, como uma rede de saneamento básico e a modernização dos dois hospitais da região, a criação de gado leiteiro, a implantação de uma indústria de laticínios, a melhoria na produção de aves e suínos e a construção de um matadouro-frigorífico. Este último figurou como peça fundamental ao crescimento econômico e desenvolvimento urbano de Itapiranga, contribuindo para atrair um volume maior de população para a área urbana e levando a ocupação para a direção oeste. Esta característica perdurou até meados da década de noventa, quando os primeiros loteamentos de habitação de interesse social foram implantados na direção norte, e foi retomada nos últimos anos com a ampliação das atividades da agroindústria em questão. Nos anos 2000, a implantação de uma instituição de ensino superior, a FAI Faculdades, e a efetivação de novas áreas industriais estimulou o crescimento direcionado na direção leste. $\mathrm{Na}$ figura 10 é representado o processo de ocupação do núcleo urbano de Itapiranga de 1926 a 2016.

O primeiro Plano Diretor Físico Territorial Urbano de Itapiranga, instituído em 1979, determinou o perímetro urbano e ordenou as zonas existentes (residencial, principal - localizada no entorno da Igreja Matriz -, comercial, industrial - correspondente à localização do frigorífico -, industrial leve, industrial pesada) e a zona de expansão. Já o Plano Diretor atualmente em vigor data de 2012. Nele estão instituídas quatro macrozonas (rural, de expansão urbana mista, de expansão urbana de interesse social e de expansão urbana residencial) e seis zonas urbanas (de interesse comercial, mista diversificada, de interesse social, de interesse residencial 1 , de interesse residencial 2 e de preservação permanente). Desta forma, com a efetivação dos planos municipais, o traçado urbano expandiu regularmente, novas ruas foram abertas e novos bairros foram criados por meio de processos de desmembramento e parcelamento do solo rural, estruturando o espaço urbano atual.

\section{CONSIDERAÇÕES FINAIS}

Em seus primeiros anos, o acesso a Itapiranga foi possível apenas por água. Desta forma, o isolamento, a vida de subsistência e a quase total ausência do estado fortaleceram o sentimento comunitário e religioso 
dos seus moradores. As influências alemãs persistem desde sua fundação, sendo representadas pela manutenção das tradições e costumes, como a língua alemã, ainda ensinada nas escolas do município e falada abertamente dentro das casas e nas ruas, a realização de festas típicas, a gastronomia, os grupos folclóricos de danças, os corais, as bandinhas alemãs, além de alguns exemplares arquitetônicos característicos remanescentes. Neste contexto, cabe destacar aqui também a paisagem resultante da interação entre as formas criadas pela natureza, os rios e morros, e o produto da ação humana, a cidade.

Na bibliografia existente sobre o município de Itapiranga, os processos de ocupação territorial, crescimento e desenvolvimento urbano não haviam sido abordados de forma a se relacionar com a história da cidade. Portanto, a presente pesquisa procurou contribuir com esses estudos. A hipótese considerada levou em consideração que a configuração urbana inicial da colônia seguia padrões de implantação das cidades criadas por alemães e seus descendentes no Brasil, uma vez que características similares podem ser encontradas em diversas cidades de colonização germânica, as quais se adequaram à paisagem natural existente em seus sítios, formada por rios, arroios e montanhas.

Demonstramos, em primeiro lugar, como a implantação da colônia estava condicionada pelo acesso a água visando à formação de uma colônia agrícola e a participação na vida comunitária. A conformação morfológica de Itapiranga contribuiu para a definição do parcelamento do solo em lotes coloniais estreitos e compridos, paralelos entre si e perpendiculares aos caminhos e com acesso aos cursos d'água. Além disso, quanto ao núcleo urbano, a estrutura do Stadtplatz se caracterizou por ter como elemento estruturador uma rua principal implantada de forma linear e paralela ao longo do rio, com casas em ambos os lados Strassenforfen. Com forte influência do relevo, os arruamentos posteriores seguiram paralelos ou perpendiculares a ela, resultando em um traçado ortogonal quando possível. Outro fator importante que pode ser confirmado é a influência da religião, uma vez que a formação da colônia estava subordinada aos preceitos católicos e ao comando de padres jesuítas.

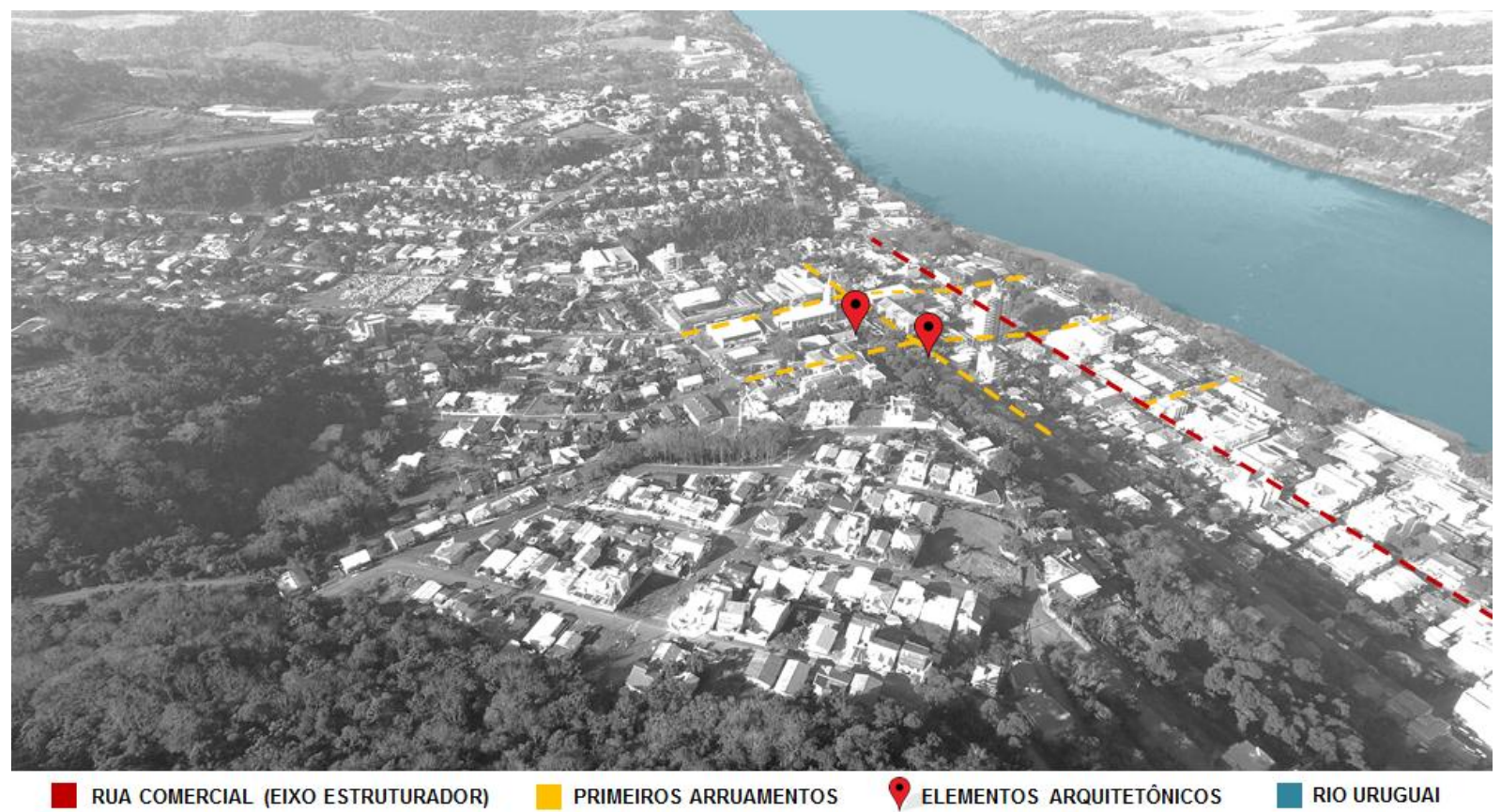

Figura 11: Vista aérea do núcleo urbano do município de Itapiranga evidenciando o principal curso d'água (rio Uruguai), o relevo envoltório demarcador da área urbana composto por morros, o eixo estruturador (rua comercial) e os demais arruamentos da ocupação inicial, bem como os elementos arquitetônicos componentes da paisagem urbana gerada (Casa Canônica/Museu e Associação Católica Kolping)

Fonte: os autores (2017).

Dessa forma, como resultados parciais da pesquisa, pode-se sustentar que houve significativa influência cultural, social e econômica na maneira como o ambiente natural foi apropriado em Itapiranga, o que refletiu diretamente na distribuição territorial e constituição dos espaços urbanos, especialmente no que diz respeito à paisagem resultante da ação antrópica sobre a natureza e à formação do Stadtplatz. O conjunto desses fatores - o curso d'água, o relevo envoltório, o arruamento estruturador e os principais elementos arquitetônicos componentes da paisagem urbana gerada - se constitui na singularidade pretendida e no patrimônio ambiental urbano da pequena cidade. 


\section{BILIOGRAFIA}

GREGORY, Valdir. (2013). Imigração alemã no Brasil. Cadernos Adenauer. Edição especial: relações Brasil-Alemanha.

HAHN, Mauro. (2005). Capital social e estratégias de desenvolvimento econômico na microrregião de Itapiranga (SC). Dissertação (Mestrado em Agroecossistemas), Programa de Pós-Graduação em Agroecossistemas, Universidade Federal de Santa Catarina - UFSC, Florianópolis.

JUNGBLUT, Roque. (2011). Porto Novo: um documentário histórico. Porto Alegre: Letra \& Vida.

- (2015): Max von Lassberg: vida - obra - tributos. Porto Alegre: Letra \& Vida.

MAYER, Leandro. (2016). Porto Novo: a materialização da "terra dos sonhos" no Extremo-Oeste de Santa Catarina na década de 1920. Revista Espaço Acadêmico (Londrina), 182, jul.

PAIM, Elison Antônio. (2006). Aspectos da constituição histórica da Região Oeste de Santa Catarina. Revista de História Saeculum (João Pessoa), jan./jun.

PELUSO JR, Victor A. (1991). Estudos de geografia urbana de Santa Catarina. Florianópolis: Editora da UFSC: Secretaria de Estado da Cultura e do Esporte, 1991.

PMI - PREFEITURA MUNICIPAL DE ITAPIRANGA. (2016). Município. 2014. Disponível em: <ht tp://www.itapiranga.sc.gov.br/municipio/index/codMapaltem/9304\#.V9jOe5grK00>. Acesso em: 02 set.

POLI, Jaci. (1987). Caboclo: pioneirismo e marginalização. Cadernos do CEOM (Chapecó), 3.

RABUSKE, Arthur; RAMBO, Arthur. (2004). Padre J. E. Rick, cientista, colonizador, apóstolo social e professor. São Leopoldo: Editora Unisinos.

RAMBO, Arthur Blásio. (2011). Somando forças - o projeto social dos jesuítas no Sul do Brasil. São Leopoldo, RS: Editora Unisinos.

RHODEN, Anderson Clayton et al. (2015). Solos do município de Itapiranga. $2^{\circ}$ Simpósio de Agronomia e Tecnologia em Alimentos. Itapiranga: FAI Faculdades.

ROCHE, Jean. (1969). A colonização alemã e o Rio Grande do Sul. Tradução de Emery Ruas. Porto Alegre: Editora Globo.

ROHDE, Maria W. (2012). Espírito pioneiro: a herança dos antepassados. 4. ed. Itapiranga: Gráfica e Editora Porto Novo.

SIEBERT, Claudia. (1999). A evolução urbana de Blumenau: o (des)controle urbanístico e a exclusão sócioespacial. Dissertação (Mestrado em Geografia), Programa de Pós-Graduação em Geografia, Universidade Federal de Santa Catarina - UFSC, Florianópolis.

WEIMER, Günter. (1983). Arquitetura da imigração alemã. Porto Alegre: Editora da Universidade.

WERLE, André Carlos. (2001). O reino jesuítico germânico nas margens do Rio Uruguai: aspectos da formação da Colônia Porto Novo (Itapiranga). Dissertação (Mestrado em História), Programa de PósGraduação em História, Universidade Federal de Santa Catarina - UFSC, Florianópolis.

WERLE, Márcio José (2007). A formação das comunidades Kolping de Itapiranga e Rio do Sul. Dissertação (Mestrado em História), Programa de Pós-Graduação em História, Universidade Federal de Santa Catarina - UFSC, Florianópolis. 